\title{
4 \\ Epidemiology of the Black Death and Successive Waves of Plague
}

\section{SAMUEL K COHN JR}

Open any textbook on infectious diseases and its chapter on plague will describe three pandemics of bubonic plague. The first, the plague of Justinian, erupted in the Egyptian port city of Pelusium in the summer of AD 541 and quickly spread, devastating cities and countryside in and around Constantinople, Syria, Anatolia, Greece, Italy, Gaul, Iberia, and North Africa: "none of the lands bordering the Mediterranean escaped it", and it reached as far east as Persia and as far north as Ireland in less than two years and spread through their hinterlands. ${ }^{1}$ Historians have counted eighteen waves of this plague through Europe and the Near East that endured until AD 750, if not longer. ${ }^{2}$ The second pandemic originated in India, China, or the steppes of Russia, touched the shores of western Europe (Messina) in the autumn of 1347, circumnavigated most of continental Europe in less than three years and eventually struck places as remote as Greenland. While the first lasted just over two centuries and the third a mere twenty-five years in pandemic form, this second wave returned periodically for nearly five hundred years in western Europe. Its last attack in Italy was at Noja (Noicattaro), near Bari, in $1815,{ }^{3}$ but it persisted longer in eastern Europe and

Professor Samuel K Cohn Jr, Department of History, University of Glasgow, 9 University Gardens, Glasgow G12 8QQ, UK.

Funding for research on this essay comes from a Wellcome Project Grant on Plague and Culture in Early Modern Italy.

\footnotetext{
${ }^{1}$ See the excellent summary of the first pandemic and its sources, Lester K Little, 'Life and afterlife of the first plague pandemic', in Lester K Little (ed.), Plague and the end of Antiquity: the pandemic of 541-750, Cambridge University Press, 2007, pp. 3-32; Ann Dooley, 'The plague and its consequences in Ireland', in ibid., pp. 215-29; and other essays in this collection. On evidence that the Justinianic plague and other waves of the "first pandemic" devastated populations in the countryside as in the cities, penetrating entire regions, see Dionysios Stathakopoulos, 'Crime and punishment: the plague in the Byzantine empire, 541-749', in ibid., pp. 99-118, p. 127. This and other essays in this collection fail to support Robert Sallares's assertion ('Ecology, evolution, and epidemiology of plague', in ibid., pp. 231-89, p. 258) that the distribution of the Justinanic plague (as well as that of the Black Death) was "patchy", and thus resembled Yersinia pestis simply because some towns and regions were spared during particular plague waves. At least for the Black Death, such an assertion flies in the face of this disease's speed and distribution, as shown by George Christakos, Ricardo A Olea, Marc L Serre, Hwa-Lung Yu, and Lin-Lin Wang, Interdisciplinary public health reasoning and epidemic modelling: the case of Black Death, Berlin, Springer, 2005. See discussion below. Doctors by the sixteenth century (even after the plague had become much less expansive than in 1348-52 and in other plagues of the fourteenth century), distinguished peste from other diseases by the extensiveness of its spread; see for instance, Discorso de Faustino Bucelleni, nel quale chiaramente si mostra da che si causano le infirmità, così delli corpi, come delle anime. Come gli orribili effetti della peste conuengono con quelli delli peccati mortali; et il securissimo porto da saluarsi da tali flagelli, Venice, n.p., 1576 (Biblioteca Apostolica Vaticana [hereafter BAV] pagination), 422v.

${ }^{2}$ On speculations that this epidemic continued beyond AD 750, see Michael G Morony, 'For whom does the writer write?: the first bubonic plague pandemic according to Syriac sources', in Little (ed.), op. cit., note 1 above, pp. 59-86, p. 67.

${ }^{3}$ Vitangelo Morea, Storia della peste di Noja, Naples, A Trani, 1817.
} 


\section{Epidemiology of the Black Death and Successive Waves of Plague}

Russia. Its cycles, however, lengthened from a hit about every ten years for any locale during the latter half of the fourteenth century to absences of 120 years or more for major cities at least in Italy by the seventeenth century. Despite repeated claims in textbooks, the plague of Marseilles in 1720-1 was not this pandemic's European finale. ${ }^{4}$ In 1743, 48,000 perished from plague in Messina; in 1770-1 over 100,000 in Moscow; and in the Balkans, Egypt, Asia Minor and Russia this Black-Death-type of contagious plague may have persisted as late as $1879 .^{5}$

The "third pandemic" began in the mid-nineteenth century and crept slowly through the Yunnan peninsula until it reached Hong Kong in 1894. From there, steamship commerce carried it across much of the world. However, except for China and India and a few other subtropical regions, its spread (unlike that of the other two pandemics) was limited in epidemic force to coastal cities and even there hardly penetrated beyond docklands. Instead of millions killed, as happened with the previous two pandemics and as Europe feared at the beginning of the twentieth century, death counts of this third pandemic in temperate zones rarely exceeded one hundred.

Few quantitative records such as burials or last wills and testaments or narrative sources that describe the signs or symptoms of plague survive for the first pandemic. But severalProcopius of Caesarea, John of Ephesus, Gregory of Tours, the Antiochene lawyer Evagrius "Scholasticus", the Chronicle of Zuqnīn, and Paul the Deacon-report swellings in the groin, armpits, or on the neck just below the ear. Like later chroniclers of the Black Death, Procopius also observed that black pustules covered victims' bodies. ${ }^{6}$

These narratives, as well as the archaeological evidence, provide certain clues about the epidemiology of the "first pandemic". It extended rapidly, not only with its first appearance in 541 but also with subsequent waves. In 664, the plague took only ninety-one days to travel 385 kilometres (as the crow flies) from Dover to Lastingham ${ }^{7}(4.23 \mathrm{~km}$ a day)—a far faster overland spread of any plague ever seen for Yersinia pestis since its discovery in 1894. At various places during the early twentieth century, such as New Orleans and South Africa, Yersinia pestis was shown to be a slow mover, travelling overland at only 12 to 15 kilometres a year. This is because Yersinia pestis is a disease of rats in which humans

\footnotetext{
${ }^{4}$ For a recent example of this common mistaken assertion, see Mark Harrison, Disease and the modern world: 1500 to the present day, Cambridge, Polity, 2004, p. 44.

${ }^{5}$ August Hirsch, Handbook of geographical and historical pathology, trans. Charles Creighton, 3 vols, London, The New Sydenham Society, 1883-6, vol. 1, p. 500, and see numerous articles in the Lancet from 1828 to 1879 describing plagues in Alexandria and other parts of Egypt, Turkey, Jerusalem, Smyrna, Persia, and the Lower Volga in Russia. I thank Professor Lars Walløe for collecting these articles and making them available to me. Some of these plagues may have been Yersinia pestis of the rat-rat-flea variety, others appear to have been more of the contagious and inter-human Black Death sort. Studies of plague in the nineteenth century before Yersin are needed. For now, see Daniel Panzac, La peste dans l' empire ottoman 1700-1800, Leuven, Peeters, 1985, where, despite his conclusions, his descriptions provide testimony of epidemics that spread rapidly throughout vast regions, killing up to 44 per cent of populations, without any evidence of prior or simultaneous epizootics of rodents.

${ }^{6}$ See the articles in Little (ed.), op. cit., note 1 above; Procopius, History of the wars, Books I-II, trans. H B Dewing, Loeb edition, Cambridge, MA, Harvard University Press, 1914; Jean-Noël Biraben and J Le Goff, 'La peste dans le haut moyen age', Annales, 1969, 24: 1492; John Maddicott, 'Plague in seventh-century England', Past and Present, 1997, 156: 7-54, esp. p. 9. For Gregory the symptoms gave the plague its name: it was lues inguinaria, "the groin plague", Gregory of Tours, The history of the Franks, trans. O M Dalton, 2 vols, Oxford, Clarendon, 1927, vol. 1, pp. 421-2; vol. 2, pp. 119, 141. Procopius, ibid., pp. 11, 22, 19-28.

${ }^{7}$ Maddicott, op. cit., note 6 above, p. 28.
} 


\section{Samuel K Cohn $\mathrm{Jr}$}

participate, to use Robert Koch's succinct definition of 1900 (now we should update it by substituting rodents for rats), ${ }^{8}$ and rats are homebound creatures. Thus modern plague, even with the advantage of railways, automobiles, and much higher population densities, would have needed twenty-five years to cover the distance this early medieval plague travelled in a mere three months. ${ }^{9}$ Connected with this great difference in the speed of transmission, a second discrepancy arises: the bubonic plague of the "third pandemic" was a rodent disease. In "typical" epidemics - those which have shown the highest mortalities in the twentieth century-ailing rats staggered drunkenly out of their hiding places and then collapsed and died, or the stench of their bodies seeped through walls and floors; a clear indication of plague to villagers and western doctors alike. ${ }^{10}$ By contrast, no scholar has found any evidence, archaeological or narrative, of a mass death of rodents that preceded or accompanied any wave of plague for the first or second pandemic. ${ }^{11}$

A third discrepancy arises from contemporary descriptions of the "first pandemic": in contrast to the "third pandemic", which never killed more than 3 per cent of the populations of major cities, the first wiped out the inhabitants of entire communities and regions, leading to mass burials or even the absence of burial altogether because of the paucity of survivors. According to the archaeological evidence, coinage, and inscriptions, its demographic effects were pivotal and long lasting. ${ }^{12}$ This overland speed and high mortality in cities and the countryside suggest a fourth discrepancy: while plague doctors of "the third pandemic" discovered to their surprise that the bubonic plague of the late nineteenth and twentieth centuries was rarely contagious, contemporaries of the first suggest a highly contagious person-to-person disease. Procopius, Evagrius, John of Ephesus, and Gregory of Tours characterized the disease as contagious and, in keeping with this trait, described it as clustering tightly within households and families; the evidence from burial sites supports their claims. ${ }^{13}$ A fifth discrepancy arises from a close correlation between plague and famine with the first, with famine often preceding and sparking a wave of plague, as seen in

\footnotetext{
${ }^{8}$ Cited in 'Reports on plague investigations in India issued by the Advisory Committee appointed by the Secretary of State for India, the Royal Society, and the Lister Institute', J. Hygiene, 1907, 7: 696.

${ }^{9}$ For existence of rats in Anglo-Saxon England, see Michael McCormick, 'Rats, communications, and plague: toward an ecological history', J. Interdiscip. Hist., 2003, 34: 1-25.

${ }^{10}$ For such observations during nineteenth-century plagues in China before 1894, see for instance, Wu LienTeh, 'Historical aspects', in Wu Lien-Teh, J W H Chun, R Pollitzer, and C Y Wu, Plague: a manual for medical and public health workers, [Shanghai], Weishengshu National Quarantine Service, Shanghai Station, 1936, pp. 13-18.

${ }^{11}$ The existence of rat remains in various places for sixth century as well as later medieval Europe is not evidence of an epizootic of rats or other rodents accompanying plague outbreaks. Sallares, op. cit., note 1 above, p. 270, tries to explain away the problem of contemporaries' failure to report rats by comparing this supposed oversight with a failure before the laboratory revolution in connecting mosquitoes with malaria, and lice with typhus. The comparison, however, is forced: a failure to see and understand insects as the vectors of a disease is hardly the same as observing what would have been the sudden death of thousands, even millions, of rats falling from rafters, littering buildings, streets and lanes, not only in 1348, but in numerous other plagues until the nineteenth century. In India and Africa, native villagers could see them and took them as the sign to leave their villages during the plague season: why would Europeans alone have been so blind or ignorant?

${ }^{12}$ See Peter Sarris, 'The Justinianic plague: origins and effects', Continuity and Change, 2002, 17: 169-82; idem, 'Bubonic plague in Byzantium: the evidence of non-literary sources', in Little (ed.), op. cit., note 1 above, pp. 119-32; Hugh N Kennedy, 'Justinianic plague in Syria and the archaeological evidence', in Little (ed.) op. cit., note 1 above, pp. 87-95; and Lawrence I Conrad, 'Epidemic disease in central Syria in the late sixth century: some new insights from the verse of Hassān ibn Thābit', Byzantine and Modern Greek Studies, 1994, 18: 50-8.

${ }^{13}$ Little, 'Life and afterlife of the first plague pandemic', op. cit., note 1 above, pp. 9, 11; Morony, op. cit., note 2 above, pp. 79-80; Sallares, op. cit., note 1 above, pp. 243, 276; and Conrad, op. cit., note 12 above, p. 28.
} 


\section{Epidemiology of the Black Death and Successive Waves of Plague}

Alexandria and Constantinople in 618 and $619 .{ }^{14}$ By contrast, dearth has tended to dampen epidemics of Yersinia pestis of the "third pandemic", while bumper crops have intensified them: increase grain yields feed higher populations of infected rats and their fleas, giving rise to higher numbers of human cases and fatalities.

Finally, the "first pandemic", like the second, but unlike "typical" bubonic plague of the Yersinia variety, could strike at any time of year before usually settling into a summer pattern for the southern Mediterranean and the Near East, that is during the hottest and driest points of the year, the least hospitable season for the most efficient flea vector of Yersinia pestis-Xenopsylla cheopis. Despite these epidemiological differences between the first and third pandemics of plague, scholars of the Justinianic plague have nonetheless been absolutely certain that the causative agent of this first pandemic must have been the bacterium, Yersinia pestis. Even more extraordinary, according to some scholars of the first, little if anything differentiated the epidemiology of the three pandemics, although the first two spread more rapidly and were more contagious than any disease ever witnessed by contemporaries, while the third, whose agent was discovered in 1894, was a slow mover, surprising health carers around the world by its lack of contagiousness. ${ }^{15}$

The narrative sources for the "second pandemic" set off by the Black Death of 1347-52 explode in number and variety. In addition to hundreds of chronicles from abbeys, citystates, and principalities across Europe, the plague tract, written principally by universitytrained doctors, takes off; by the fifteenth century, it had become one of the earliest forms of "popular literature". ${ }^{16}$ Further, the survival of tens of thousands of last wills and testaments, monastic and confraternity necrologies, burial records, manorial rolls, lists of ecclesiastical vacancies, and doctors' examinations of causes of death allow quantitative analyses of the late medieval and early modern plagues: their cycles of mortality, seasonality, topographical details of transmission, and some basic characteristics of the victimsage, sex, occupation, class, and locality. Among these riches, neighbourhood burial records exist for Siena in 1348 and a city-wide one for Givry in Burgundy during the plague's first onslaught in 1348-9. In Arezzo, they begin in the 1370s and in Florence in the 1420s. By 1452, Milanese doctors and health workers examined all city deaths and supplied detailed clinical reports for each body. Similar records (although lacking the rigorous medical observation of victims' symptoms and signs as seen in the Milanese death books) appear for cities north of the Alps during the second half of the fifteenth century. ${ }^{17}$

\footnotetext{
${ }^{14}$ Stathakopoulos, op. cit., note 1 above, p. 116. For other examples, see Morony, op. cit., note 2 above, p. 70 , for the plague waves of 743 and 744, and p. 84, for the plagues of 744-745 in Mesopotamia, Bostra and the Hawran.

${ }^{15}$ Despite these positive identifications (see Little (ed.), op. cit., note 1 above, pp. 2-3, 44, 65, 99, 120, 236, and 238), only the essay by Sallares (op. cit., note 1 above, pp. 231-89) even considers epidemiology; and only that by Michael McCormick expresses any possibility that the case for Yersinia pestis as the agent of the first two pandemics may still be open to further historical and microbiological research ('Toward a molecular history of the Justinianic pandemic', in Little (ed.), ibid., pp. 290-312). For another recent but more balanced view that does not presume that discussion has ended, see Peregrine Horden, 'Mediterranean plague in the age of Justinian', in Michael Maas (ed.), The Cambridge companion to the age of Justinian, Cambridge University Press, 2005, pp. 134-60, and esp. pp. 143-53.

${ }^{16}$ Arturo Castiglioni, "Ugo Benzi da Siena ed il "Trattato utilissimo circa la conservazione della sanitate", Rivista di Storia Critica delle Scienze Mediche e Naturali, 1921, 12: 75.

${ }^{17}$ See Carlo Cipolla, 'I Libri dei morti', Le Fonti della Demografia storico in Italia, 1972, 2: 851-66.
} 


\section{Samuel K Cohn $\mathrm{Jr}$}

Yet, despite this surfeit of information, no evidence links any late medieval or early modern European plague from 1347 to the end of the eighteenth century to a description or even suspicion of an epizootic of rodents that preceded or accompanied human plague. The closest claim for such a connection has been the doctors' repetition of Avicenna's tenthcentury cliché about the remote cause of epidemics in general: the inversion of naturebirds dropping from their nests in mountaintops to lower valleys and underground beings such as topi rising to the surface as the harbingers of epidemics. Moreover, in this flip-flop of nature, doctors did not note mice and rats taking centre stage; rather they pointed to snails, frogs, scorpions, snakes, bugs, and other subterranean creatures surfacing from their holes, and, unlike the drunken prance of rats that soon dropped dead on doorsteps, as poignantly described in Camus's La peste, these underground creatures climbed out in the bloom of health. ${ }^{18}$ Occasionally, in the early modern period, contemporaries even described the increased number and vigour of live mice and rats during plague time, the direct result, as they probably rightly surmised, of governments' systematic culling of the domestic cat populations. ${ }^{19}$

The epidemiological evidence that can be assembled from the late medieval and early modern sources raises further doubts that the so-called second pandemic was the same disease as the bubonic plague that spread to ports globally at the end of the nineteenth century. First, like the early medieval plague, the "second pandemic" was a fast mover, travelling in places almost as quickly per diem as modern plague spreads per annum. George Christakos and his co-researchers have recently employed sophisticated stochastic and mapping tools to calculate the varying speeds of dissemination and areas afflicted by the Black Death, 1347-51, through different parts of Europe at different seasons. They have compared these results to the overland transmission speeds of the twentieth-century bubonic plague and have found that the Black Death travelled at 1.5 to 6 kilometres per day-much faster than any spread of Yersinia pestis in the twentieth century. ${ }^{20}$ The area of Europe covered over time by the Black Death in the five years 1347 to 1351 was even more impressive. Christakos and his colleagues maintain that no human epidemic has ever shown such a propensity to cover space so swiftly (even including the 1918 influenza epidemic). By contrast to the spread of plague in the late nineteenth and twentieth centuries the difference is colossal: while the area of Europe covered by the Black Death was to the

\footnotetext{
${ }^{18}$ References to such supposed pre-plague events abound in plague tracts; see for instance, Marsilio Ficino, Consiglio contro la pestilenza, ed. Enrico Musacchio, Bologna, Capelli, 1983, p. 57; Michele Savonarola, I trattati in volgare della peste e dell' acqua ardente, ed. Luigi Belloni, Milan, n.p., 1963, p. 8; 'Ein italienischer Traktat "De pistelencia", in Archiv für Geschichte der Medizin, 1913, 6: 353-55, p. 353; 'Der Pesttraktat des Pietro di Tussignano (1398)', in ibid., 1912, 5: 390-95, pp. 394; 'Der Pesttraktat Meisters Peter von Kottbus', in ibid., 1919, 11: 121-32, p. 125; 'Collectorium minus' (Prague Medical Faculty, around 1406), in ibid., 1916, 9: 120, 128; 'Aliqua breuia dubia circa materiam de Epidemia in Montepessulano conscripta' (by a follower of Bernard Gordon, beginning of the fifteenth century), in ibid., 1925, 17: 40-3, p. 40; Il Libro della Pestilenza di Giovanni de Albertis, ed. Arturo Castiglioni, Bologna, in Archeografo Triestino, 1924, ser. 3, 39: 163-229, p. 200; Alessandro Simili, 'Saladino Ferro da Ascoli', in Atti e Memorie dell' Accademia di Storia dell' arte Sanitaria, 1963, 29: 26-46, p. 40; and Arturo Castiglioni, 'I libri italiani della pestilenza', in idem, Il Volto di Ippocrate: Istorie di Medici e Medicine d'altri tempi, Milano, Società editrice Unitas, 1925, pp. 145-69, p. 165.

${ }^{19}$ See, for instance, Giovanni Filippo Ingrassia, Informatione del pestifero, et contagioso morbo, il quale affligge et have afflitto questa città di Palermo \& molte altre città e Terre di questo Regno di Sicilia, nell' anno 1575 et 1576, Palermo, Giovan Mattheo Marda, 1576, pp. 67, 228.

${ }^{20}$ Christakos, et al., op. cit., note 1 above, pp. 223, 230.
} 
4th power of time between 1347 and 1351, that of the bubonic plague in India between 1897 and 1907 was to the 2nd power of time, a difference of two orders of magnitude. ${ }^{21}$ Furthermore, it should be noted that the spread of bubonic plague in India at the turn of the twentieth century was exceptional. Since 1894,95 per cent of cases of this plague have occurred in India. If these scientists had compared the time-space propagation of the Black Death with other twentieth-century regions of plague, even subtropical ones such as China, the differences in orders of magnitude would be greater still.

Doctors and chroniclers marvelled at the Black Death's lightning transmission, reporting that mere speech was enough to pass it directly and immediately from one person to the next. Tales of sailors leaving their ships and infecting local populations instantly cannot be attributed merely to fear and exaggeration by stunned observers in 1347 and 1348 as some have asserted. ${ }^{22}$ Nor is it reasonable to assume that somehow the plague mysteriously raced ahead of the ships docking in Messina's harbour in October 1347 and it was mere coincidence that the resident population began dying at the very moment when the sailors from the east happened to disembark, or that these Black Death chroniclers simply pointed to the sailors as convenient scapegoats for the disease, as Susan Scott and Christopher Duncan have asked us to believe. ${ }^{23}$ Towards the end of the European plague experience, the Enlightenment doctor and polymath Richard Mead, using contemporary reports from the plagues of Rome in 1656, Marseilles in 1719, and Messina in 1743, recorded the same rapid infection of dock workers, sailors, and magistrates who inspected ships and cargo at the beginning of these later European plagues. In almost every case, these plague officials could identify the spread of the disease as the immediate consequence of an infected ship's dropping anchor in a port. Mead was astonished how rapidly victims could die from the time of first exposure to plague; for example, "the Porters who opened the infected Bales of Goods in the Lazaretto's [sic] of Marseilles, died upon the first Appearance of Infection, as it were by a sudden stroke ... death insued sometimes in a few hours". 24

Before 1348 the word contagium (contagion) was rarely used, especially outside the medical profession. When chroniclers and theologians used the term, it applied almost

${ }^{21}$ Ibid., pp. 205-7, 230.

${ }^{22}$ See, for instance, the chronicle of the Franciscan Michele da Piazza or of the Sienese merchant, Agnolo di Tura, Il Grasso, who claimed that victims "died almost at once: with the swelling under the arms and in the groin, they fell dead while talking [favellando]", Cronaca senese attribuita ad Agnolo di Tura, in Cronache Senesi, ed. A Lisini and F Iacometti Rerum Italicarum Scriptores (hereafter R.I.S.), vol. 15, part 6.1, Bologna, NZanicheli, 193137, p. 555. For the assertions of Susan Scott and Christopher Duncan, see their Return of the Black Death: the world's greatest serial killer, Chichester, Wiley, 2004, p. 155.

${ }^{23}$ Christakos, et al., op. cit., note 1 above, p. 231. The authors admit that the descriptions of chroniclers do not match the long incubation period of 32 days and a 37-day infectious period argued by Susan Scott and Christopher Duncan, Biology of plagues: evidence from historical populations, Cambridge University Press, 2001, pp. 24, 128-9; and Return of the Black Death, op. cit., note 22 above, pp. 155-61. Scott and Duncan's conclusions are based on an unexplained sample of nine households in their first book and three (taken from the previous nine) in the second. These have been selected from 242 plague-stricken households reconstructed at Penrith, Cumbria, with a similarly small sample taken from parish burial records during the plague at Eyam. Their results and assumptions about the transmission of infectious diseases are challenged in Samuel K Cohn Jr and Guido Alfani, "Households and plague in early modern Italy', J. Interdiscip. Hist., 2007, 38: 177-205, esp. pp. 181-7. For the Milanese plagues 1452 to 1523 and at Nonantola (Modena) during the plague of 1630, using over a thousand reconstructed households, as much as a quarter of plague deaths within households occurred within twenty-four hours of one another. This interval (zero days) was the mode of plague deaths within households.

${ }^{24}$ Richard Mead, A discourse on the plague, 9th ed., London, 1744, pp. 48. 


\section{Samuel K Cohn $\mathrm{Jr}$}

exclusively to heresy or revolt and not to disease. By contrast, after 1348 its usage became widespread and not only among doctors. Chroniclers and merchants in their diaries and letters used it to describe the spread and destruction wrought by disease and principally by plague. ${ }^{25}$ By contagion, they clearly meant person-to-person transmission by breath, touch, or occasionally by sight, and, although the term was applied to other maladies, it was mainly reserved for describing plague, in order to distinguish it from other diseases. ${ }^{26}$ Early on, contagion and the swiftness of death became as important "pestilential accidents" as the bubo to identify their new disease and to differentiate it from others such as pondi, dondi, or smallpox, which contemporaries often saw as producing similar skin afflictions. Thus in England a chronicler known as the Brut described a 1369 epidemic that combined smallpox and plague. He distinguished between the two, not by the diseases' signs but on elementary epidemiological grounds, pointing to the levels of contagion and the speed of the death: with "pestilens" people went to bed healthy, "hool \& in good poynt", and "suddenly they died"; whereas smallpox ("an illness that men callen "the pokkes",) was "much slower to infect both men and women". ${ }^{27}$ In 1390 the merchant chronicler of Florence, known as the pseudo-Minerbetti, also observed two diseases that he saw as concurrent, spreading through parts of the territory of Florence. In terms of seasonalitythe summer months - and skin disorders that spread over the victims' bodies, he claimed the two were indistinguishable, but he nonetheless made a distinction between them, as did the English chronicler, on epidemiological grounds: one, which Minerbetti called pondi, moved slowly, while the other was the fast mover and quick killer, the plague. ${ }^{28}$ In addition, Florentines such as the merchant Giovanni Morelli had grown only too well accustomed to the new "big killer" after it had appeared in the city five times since 1348 . Morelli also turned to epidemiological patterns to recognize this disease by noting its exceptional contagiousness and high mortalities as well as its seasonality: regularly, it made a faint appearance in Florence at the end of winter with only a few hidden cases and smouldered until the first heat waves in May, which set the plague ablaze with a mounting

\footnotetext{
${ }^{25}$ Samuel K Cohn Jr, 'Notions of disease and the Black Death', paper given at Cambridge to the History of Medicine Seminar, 20 January 2004, organized by Andrew Cunningham. For the use and development of the notion of contagion in the medical literature, see Vivian Nutton, 'Seeds of disease', Med. Hist., 1983, 27: 1-34; and idem, 'The reception of Fracastoro's theory of contagion: the seed that fell among the thorns', Osiris, 2nd series, 1990, 6: 196-234. By the sixteenth century doctors described a number of diseases as contagious, such as petecchie, but distinguished plague as far more contagious with the added capacity of spreading by distance and not just by contact with infectious persons or infected objects; see, for instance, Giuliano da Marostica, Copia d' vna lettera dello eccellente ... Giuliano da Marostica treuisano in materia di medicar la peste, \& le petecchie, \& di preseruar dall' uno, \& l' altro male, Venice, n.p., 1556, 309v; and Girolamo Fracastoro, Il contagio: le malattie contagiose e la loro cura, trans. Vincenzo Busacchi, Florence, Leo S Olschki, 1950, p. 13. These definitions and descriptions will be further developed in a book on plague literature in the sixteenth-century that I am now writing: Evolutions of plague: disease and thought in sixteenth-century Italy.

${ }^{26}$ Early on the term was used by scholars for diseases such as leprosy. For the split between scholarly and medical usage of the term, on the one hand, and popular or "superstitious" usage, on the other, in early medieval Muslim culture, see Lawrence I Conrad, 'A ninth-century Muslim scholar's discussion of contagion', in Lawrence I Conrad and Dominik Wujastyk (eds), Contagion: perspectives from pre-modern societies, Aldershot, Ashgate, 2000, pp. 163-77.

${ }^{27}$ The Brut or The chronicles of England, ed. Friedrich W D Brie, Early English Text Society, no. 136, London, Kegan Paul, Trench, Trübner for the Early English Text Society, 1906 p. 316.

${ }^{28}$ Cronica volgare di anonimo fiorentino dall' anno 1385 al 1409 già attribuita a Piero di Giovanni Minerbetti, ed. Elina Bellondi, R.I.S., vol. 27, part 2, Città di Castello, S Lapi, 1915-18, p. 110.
} 


\section{Epidemiology of the Black Death and Successive Waves of Plague}

death toll that would peak in June or early July. ${ }^{29}$ In plague tracts of the fifteenth and sixteenth century, plague was often called simply "the contagion"-morbo contagioso, contagioso male, voracissimo contaggio ${ }^{30}$ — and for many the first distinguishing factor of "true plague" was precisely this, that it was the most contagious of diseases. ${ }^{31}$

Similarly, by the end of the so-called second pandemic, commentators such as Mead continued to emphasize the plague's contagion and its capacity to spread rapidly. For this reason he advised against "Crowding the Sick together in Hospitals", claiming that it "can serve to no good purpose; but instead thereof will promote and spread the Contagion". 32 He too distinguished plague from other illnesses that gave rise to boils and pustules by turning to the disease's extraordinary contagion, ${ }^{33}$ and, because of this, used his plague pamphlet to preach the benefits of quarantine. ${ }^{34}$

There is indeed usually some difference between these Swellings in the Plague, and in other Fevers, especially in the time of their coming out: for in the Plague they discover themselves sooner than in most other Cases. But the principal difference between these Diseases, is, that the Plague is infectious, the other not; as least not to any considerable Degree.

And this leads me to another Character of this Disease, whereby it is distinguished from ordinary Fevers, which is the Contagion accompanying it. ${ }^{35}$

In contrast to this defining characteristic of the Black Death and its subsequent waves through the eighteenth century, doctors and health workers at the turn of the twentieth century, from Bombay to Sydney, in one hospital after another, remarked to their great surprise that the safest place to be in time of plague was the plague ward. ${ }^{36}$ Despite the habits of Indian relatives crowding round plague victims in plague hospitals and passing the patient's sputum from one relative to the next, Yersinia pestis rarely had pneumonic complications (primary or secondary) and was even more rarely spread by contaminated

\footnotetext{
${ }^{29}$ Giovanni di Pagolo Morelli, Ricordi, in Mercanti scrittori: ricordi nella Firenze tra medioevo e rinascimento, ed. Vittore Branca, Milan, Rusconi, 1986, p. 207.

${ }^{30}$ See, for instance, Paolo Bisciola, Relatione verissima del progresso della peste di Milano, Ancona, Carlo Melisardi, ad instanza di Sebastiano Balestra, 1577, 2r, 3v.

${ }^{31}$ See, for instance, Practica Antonii Guainerii papiensis doctoris clarissimi et omnia opera de peste, Venice, J P de Leucho, 1508, 95v; Decem problemata de peste per Victorem de Bonagentibus medicum, Venice, Vicentij Valgrisij, 1565, p. 3; Michele Mercati, Instruttione sopra la peste: nella quale si contengono i piu eletti \& approvati rimedij, con molti nuovi e potenti secreti, Rome, Vincento Accolto, 1576, p. 2; De pestilentia Hieronymi Mercurialis Foroliviensis medici praeclarissimi lectiones habitae Patavii, Venice, Paulum Meietum, 1577, pp. 10-11; Andrea Gabrielli, De peste, opus perutile, ac praesidio locupletissimorum, Bologna, Peregrinum Bonardum, 1577[?], 3r, and see note 22.

${ }^{32}$ Mead, op. cit., note 24 above, p. xviii.

${ }^{33}$ Ibid., pp. 10-11.

${ }^{34}$ Ibid., pp. xxxiii, xxxviii, 58, 66-7, 80-99. As with doctors in the late fourteenth and fifteenth centuries, a notion of contagion brought on by direct contact with goods or other persons was not seen as contradicting theories of miasma: "A corrupted State of Air is, without doubt, necessary to give these contagious Atoms their full force," ibid., p. 66.

${ }^{35}$ Ibid. p. 11.

${ }^{36}$ For this observation, see Samuel K Cohn Jr, The Black Death transformed: disease and culture in early Renaissance Europe, London, Arnold; and New York, Oxford University Press, 2002, pp. 122-3. In 1897, Brigadier-General W F Gatacre even quantified it in his plague report from the hospitals of the Presidency of Bombay, Report on the bubonic plague in Bombay, 1896-97, Bombay, Times of India, 1897, p. 94: "Of about 400 people ... who either visited their sick friends or remained constantly by their bedsides ... in not a single instance did any of these persons contract the plague."
} 


\section{Samuel K Cohn Jr}

clothes or goods (other than rat-infested grain). Instead, it depended largely on the complex and inefficient mechanisms of the rat carrier and rat-flea vector. ${ }^{37}$ Moreover, despite two serious epidemics of pneumonic plague in Manchuria in 1911 and 1922, several outbreaks of plague in which Pulex irritans may have been the ectoparasite, and plague deaths resulting from handling skins of marmots, squirrels, cats, and other carriers, or from the consumption of diseased camel meat, the vast majority of plague cases from 1894 to today (certainly over 95 per cent of them) have resulted from rodent fleas feeding off rodents (principally rats) and then biting and regurgitating the bacillus into humans.

Thirdly, the seasonality of the late medieval plagues does not resemble that of modern plague. Because of the flea vector, Yersinia pestis in bubonic form is sustained at epidemic levels only within a narrow temperature band $\left(10^{\circ} \mathrm{C}\right.$ to $\left.25^{\circ} \mathrm{C}\right)$, accompanied by high levels of relative humidity. On the other hand, bouts of late medieval plague could occur at any time of year, including January in places as inhospitable to the subtropical rat flea (Xenopsylla cheopis or the European one, Nosopsyllus fasciatus) as Norway, Sweden, and Scotland. ${ }^{38}$ Further, in the warmer Mediterranean, the Black Death and its recurrent strikes consistently peaked at the warmest and driest points of the year (June and July), the least likely months for modern plague to spread, given the fertility cycles of fleas and especially that region's most prevalent rat flea. ${ }^{39}$ Cases of Yersinia pestis in the Mediterranean zones during the twentieth century (although few in number) have followed closely the fertility cycle of Nosopsyllus fasciatus, whose numbers and fertility peak in late September to November ${ }^{40}$ with corresponding human cases in Mediterranean towns such as Taranto in September to November. ${ }^{41}$ Thus, these Italian twentieth-century plague cases have arisen two to three months after plague had declined or disappeared entirely in Florence, Bologna, Rome, and other cities during the fourteenth and fifteenth centuries. In fact, the time when late medieval plague most often peaked in Bologna, Tuscany, Umbria, and Rome was June, the very month when the appearance of Nosopsyllus fasciatus reaches its nadir in Mediterranean Europe. ${ }^{42}$ It is, therefore, even less likely that an eruption of Yersinia pestis will occur in June in these zones than in January. ${ }^{43}$

\footnotetext{
${ }^{37}$ On the difficulties of flea blockage and transmission even with ideal conditions of temperature and high humidity, see Albert L Burroughs, 'Sylvatic plague studies: the vector efficiency of nine species of fleas compared with Xenopsylla cheopis', J. Hygiene, 1947, 45: 371-96.

${ }^{38}$ For the continuation of plague through the winter months in England, 1348-9, see numerous chronicle descriptions and the last wills and testaments from the Court of Husting: of the five highest monthly counts of deathbed wills, three were during the cold months of January to March 1349; see Cohn, op. cit., note 36 above, p. 184. For the Black Death in Bergen, Norway, in January, see Ole Jørgen Benedictow, Plague in late medieval Nordic countries: epidemiological studies, Oslo, Middelalderforlaget, 1992, p. 44. For plague in Trondheim, Norway, that peaked in February 1566 and many other examples of winter outbreaks in Scandinavia, see Lars Walløe, Plague and population: Norway 1350-1750, Avhandlinger (Norske videnskaps-akademi), new series, No. 17, Oslo, University of Oslo, Department of Physiology, 1995, pp. 25 passim.

${ }^{39}$ For these seasonal charts of plague, see Cohn, op. cit., note 36 above, pp. 156-73, 182-5.

${ }^{40} \mathrm{~J}$ C Gauthier and A Raybaud, 'Des variétés de pulicidés trouvés sur les rats à Marseille', Comptes Rendus hebdomadaires des Séances et Mémoires de la Société de Biologie, 1909, 67: 196-9.

${ }^{41}$ Robert Pollitzer, Plague, Geneva, World Health Organization, 1954, p. 30.

${ }^{42}$ Gauthier and Raybaud, op. cit., note 40 above, p. 198. From a count at Marseilles between 1906 and 1909, with 10,000 collected fleas on rats, June ranked as the month at the absolute low-point of flea numbers.

${ }^{43}$ In northern Italian cities such as Milan and Venice from the late fifteenth to the seventeenth century, the variability in plague season seems to have changed from its Mediterranean pattern during the plague's first hundred years. The Milanese plagues of 1485 and 1503 peaked in October, in 1468 it peaked in May, and in 1523 in July and
} 


\section{Epidemiology of the Black Death and Successive Waves of Plague}

Fourthly, modern plague has never attained the mortalities seen with major strikes of the Black Death or even with most of its subsequent assaults. In the summer months of 1348 alone, tax records show that Florence lost three-quarters of its population or more. ${ }^{44}$ It is clear from manorial records that villages in Cambridgeshire, ${ }^{45}$ the bishopric of Worcester, ${ }^{46}$ and the area around St-Flour (Auvergne) ${ }^{47}$ lost up to 80 per cent of their populations. According to chroniclers, places such as Trapani on the west coast of Sicily became totally abandoned after $1348 .^{48}$ Further, although later strikes of plague in the seventeenth century were not as widespread as waves of the Black Death in the latter half of the fourteenth century, they could be as devastating for cities such as Genoa and Naples in 1656-7, which had not experienced plague for 120 years. Both lost two-thirds of their populations. ${ }^{49}$ By contrast, modern plague has never approached these levels of human destruction-not even in India, where over 95 per cent of twentieth-century plague casualties have occurred. The highest mortality for any large city in any plague year was at Bombay City in 1903, when less than 3 per cent of its population perished from plague.

True, in the countryside and in small villages, the proportion killed by bubonic plague rose higher. In several villages in the Punjab (the region most devastated by Yersinia pestis in any form since the bacillus was discovered), mortality rates may have reached 30 per cent. But, as E H Hankin speculated in $1905^{50}$ and Major Greenwood demonstrated with

August (ASM, Fondo popolazione, parte antica, nn. 73, 77, 80, and 87). Great variability, unknown with any two strikes of Yersinia pestis within the same locale, is seen with Venice's last two and perhaps most devastating plagues in 1575-77 and 1630-31. The first peaked in July 1576; the second in November 1630; see Paolo Preto, 'Peste e demografia: L'età moderna: le due pesti del 1575-77 e 1630-1', in Venezia e la peste 1348/1797, Comune di Venezia, Venice, Marsilio, 1979, pp. 97-102.

${ }^{44}$ Over the past fifty years estimates of the pre-plague population of Florence vary between Giovanni Villani's figure of 90,000 and 133,000. Based on baptismal evidence, food consumption and the scrupulous estimates of the early fifteenth-century diary of Giovanni Morelli, op. cit., note 29 above, p. 209, historians have moved towards the upper figure of 120,000. See David Herlihy and Christiane Klapisch-Zuber, Les Toscans et leurs familles: une étude du "catasto" florentin de 1427, Paris, Fondation Nationale de Sciences Politiques, 1978, pp. 173-7; and William R Day, Jr, 'The population of Florence before the Black Death: survey and synthesis', J. Mediev. Hist., 2002, 28: 93-129. According to a tax survey of 1351, the population of Florence was 40,000. Niccolò Rodolico, La Democrazia fiorentina nel suo tramonto (1378-1382), Bologna, Zanichelli, 1905, pp. 38-45, argued, however, that peasants flocking from the countryside during the immediate aftermath of the plague swelled the population of Florence well above its level in the autumn of 1348. He estimated that the plague had cut the Florentine urban population to 25,000 or lower. This figure, moreover, corresponds roughly with the observations of Morelli, who estimated that 80,000 Florentines died in 1348 (p. 209).

${ }^{45} \mathrm{~J}$ Z Titow, English rural society 1200-1350, London, Allen and Unwin, 1969, pp. 69-71; and Francis M Page, The estates of Crowland abbey, Cambridge University Press, 1934, pp. 120-5.

${ }^{46}$ Richard Lomas, 'The Black Death in County Durham', J. Mediev. Hist., 1989, 15: 127-40, pp. 129-30.

${ }^{47}$ Henri Dubois, 'La dépression: $\mathrm{XVI}^{\mathrm{e}}$ et $\mathrm{XV}^{\mathrm{e}}$ siècles', in Jacques Dupâquier, et al., Histoire de la population française, 4 vols, Paris, Presses Universitaires de France, 1988, vol. 1, p. 321.

${ }_{48}$ Cronica B in Corpus Chronicorum Bononiensium, ed. Albano Sorbelli, R.I.S., vol. 18, part 1, Città di Castello, S Lapi, 1906-39, vol. 2, p. 584; Storie pistoresi (MCCC-MCCCXLVIII), ed. Silvio Adrasto Barbi, RIS, vol. 11, part 5, Città di Castello, S Lapi, 1914, p. 235; Historia Miscella Bononiensis ab anno MCIV usque MCCXCIV auctore prasertim Fratre Bartolomao Della Pugliola Ordinis Minorum. Continatio usque MCCCCLXXI, ed. L A Muratori, R.I.S., vol. 18, Milan, ex typografia Societatis Palatinae, 1732, col. 409; Polyhistoria Fratris Bartholomaei Ferrariensi Ord. Praed. MCCLXXXVIII usque ad annum MCCCLXVII, ed. L A Muratori, R.I.S., vol. 24, Milan, ex typografia Societatis Palatinae, 1723, col. 806.

${ }^{49}$ On Genoa and Naples, see Carlo Cipolla, I pidocchi e il Granduca: crisi economica e problemi sanitari nella Firenze del '600, Bologna, Il Mulino, 1979, p. 79. Further, the plague of 1630 in Venice killed as many as 80,000. The previous serious plague occurred two generations earlier; S R Ell, 'Immunity as a factor in the epidemiology of medieval plague', Rev. Infect. Dis., 1984, 6: 866-79, p. 872.

${ }^{50}$ E H Hankin, 'On the epidemiology of plague', J. Hygiene, 1904, 5: 48-83, p. 58. 


\section{Samuel K Cohn Jr}

statistical rigour seven years later, ${ }^{51}$ the case and mortality rates of bubonic plague were inversely correlated with human population because of Yersinia pestis' reliance on a pool of diseased rodents and not on the density or absolute figures of human population. Recently, Ole J Benedictow has vigorously tried to demonstrate that Black Death demographics followed a similar pattern. But, despite his efforts to scale down the mortalities in large cities and magnify them for smaller places, his own figures still fail to show any such inverse correlation. ${ }^{52}$ Christakos and his co-authors have argued cautiously that the mortality figures for 1347-51 show no correlations, positive or negative, between the size of a place and the epidemic's mortality. ${ }^{53}$ However, according to population estimates supplied in tax records in late fourteenth- and fifteenth-century Tuscany, mortality levels were roughly higher the larger the population of a city or town. ${ }^{54}$ Furthermore, by the sixteenth century in England, France, and Italy, the contrasts between cities and countryside became more marked, leading contemporaries and historians to conclude that plague was essentially a disease of towns and of overcrowding. ${ }^{55}$

Fifthly, the cycles and trends of the "second pandemic" differed strikingly from those of the "third". Because humans possess little or no natural immunity to Yersinia pestis and cannot acquire it over the long term, ${ }^{56}$ mortality rates from this bacillus do not fall steadily as a population becomes more accustomed to the pathogen. Thus in India plague mortalities first increased for a decade or more, then jumped randomly from year to year before declining in the 1920s, as a result of rats (not humans) acquiring immunity to the bacillus. ${ }^{57}$

\footnotetext{
${ }^{51}$ M Greenwood, 'Statistical investigation of plague in the Punjab. Third report', in J. Hygiene: Plague Supplement I, 1911, pp. 62-156; and idem, Epidemics and crowd-diseases, London, Williams and Norgate, 1935.

${ }^{52}$ Ole J Benedictow, The Black Death, 1346-1353: the complete history, Woodbridge, Boydell Press, 2004, pp. 284-6, 296, 307, and my review of it in N. Engl. J. Med., 2005, 352: 1054-5.

${ }^{53}$ Christakos, et al., op. cit., note 1 above, p. 148.

${ }^{54}$ On mortality estimates during the Black Death for Florence, Siena, Pisa, Prato, Pistoia, San Gimignano and other places in Tuscan, see Herlihy and Klapisch-Zuber, note 44 above, pp. 166-7, 177-81.

${ }^{55}$ For sixteenth-century England, see Paul Slack, The impact of plague in Tudor and Stuart England, 2nd ed., Oxford, Clarendon, 1990, pp. 99, 110, 152, 159; for France, Jean-Noël Biraben, Les hommes et la peste en France et dans les pays européens et méditerranéens, 2 vols, Paris, Mouton, 1975, vol. 1, pp. 287, 299-302, 307. For notions of contemporary doctors that overcrowding and bad housing were causes of plague in sixteenth-century Italy, see, for instance, Andrea Gratiolo di Salò, Discorso di peste, nel quale si contengono utilissime speculationi intorno alla natura, cagioni, e curatione della peste, con un catalogo di tutte le pesti piùnotabili de' tempi passati, Venice, n.p., 1576, pp. 16-18; and Tommaso Somenzi, De morbis, qui per finitimos populos adhuc grassantur, Cremona, Christophorum Draconium, 1576, 31v-32r.

${ }^{56}$ Pollitzer, op. cit., note 41 above, p. 133, concluded: "No convincing evidence is available to show that a natural immunity to insect-borne plague exists in man". And for pneumonic plague: "there can be little doubt that instances of natural resistance to pneumonic plague infection exist; [but] these are of such rare occurrence as to be of no practical importance” (p. 511). Also, see Pollitzer, 'Immunology', in Wu Lien-Teh, et al., op. cit., note 10 above, pp. 92-138, esp. p. 114. More recent textbooks have followed Pollitzer's conclusions; for instance, the most used of the manuals for tropical diseases, Manson's tropical diseases, ed. P E C Manson-Bahr, D R Bell, 19th ed., London, Baillière Tindall, 1987, p. 591. "There is no known natural immunity to plague. Acquired immunity is short-lived and there is no protection against second attacks. This is borne out by the short-lived protection provided by vaccination." Also, see Darwin Palmer, 'Plague', in Sherwood L Gorbach, John G Bartlett, Neil R Blacklow (eds), Infectious diseases, 2nd ed., Philadelphia, Saunders,1998, pp. 1568-75, p. 1571. Because of contained V and W antigens, however, the Yersinia pestis organisms are able to grow and resist intracellular killing, with eventual destruction and lysis of the cell. See also Michel Signoli, Elisabeth Carniel, and Olivier Dutour, 'La peste: aspects épidémiologiques actuels et passés', in Bruno Bizot, Dominique Castex, Patrick Reynaud, and Michel Signoli (eds), La saison d'une peste: avril-septembre 1590, le cimetière des Fédons à Lambesc (Bouches-du-Rhône), Paris, CNRS, 2005, pp. 69-80, p. 72.

${ }^{57}$ For these plague trends, see Cohn, op. cit., note 36 above, pp. 190-1.
} 


\section{Epidemiology of the Black Death and Successive Waves of Plague}

Similar patterns can be seen in Brazil, Thailand, Vietnam, and other subtropical regions later in the century, even after the introduction of DDT, the use of effective antibiotics, and modern sanitary measures. ${ }^{58}$ Moreover, in subtropical zones, where plague at the end of the nineteenth and early twentieth centuries scored by far its highest mortalities, the disease returned annually to the same localities five to ten years running, and in villages of the Punjab and the Presidency of Bombay for twenty years or more. Finally, the age range of victims of modern plague has not changed significantly over the past 112 years of the third pandemic's history. As with the first strike on virgin-soil populations, those in the prime of life, between the ages of twenty and forty, have remained most often this plague's principal victims. ${ }^{59}$

By contrast, the plague cycles of the Black Death and its subsequent strikes over the first hundred years of its history were radically different. Firstly, Scott and Duncan maintain that during the initial sweep of plague, 1347 to 1353, not a single place was re-infected two or more years running, ${ }^{60}$ which is all the more remarkable given Pope Clement VI's decision to call a jubilee year for Rome in 1350. Pilgrims from northern and eastern Europe, where plague was just beginning to rage, travelled southward; yet I know of no reports of any locality being re-infected by this movement of persons and, no doubt, pathogens. The absence of re-infection, I would speculate, resulted at least in part from the immunity these individuals had acquired to their bacillus or virus, one that had outlasted the six months or less that humans today can acquire to resist Yersinia pestis.

Secondly, the mortality trends across Europe illustrate a remarkable tendency for the pathogen of the Black Death and its human hosts to adapt, again unlike the trends reflected in cases and mortality from Yersinia pestis in India and elsewhere during the late nineteenth and twentieth centuries. ${ }^{61}$ Contemporaries were aware of the Black Death trend and attributed the sharp decline in morbidity and mortality of successive strikes of plague to their own scientific and political intervention. After four strikes of plague in Avignon, the pope's personal doctor Raymundus Chalmelli de Vinario gave a retrospective in 1382 on their plague experience since the Black Death:

In 1348, two thirds of the population were afflicted, and almost all died; in 1361, half the population contracted the disease, and very few survived; in 1371, only one tenth were sick, and many survived; while in 1382, only one twentieth of the population became sick, and almost all of these survived. ${ }^{62}$

\footnotetext{
${ }^{58}$ See the tables in Pollitzer, op. cit., note 41 above, pp. 22-27, 56-9.

${ }^{59}$ For the age cluster, 21 to 40 , see ibid.,pp. 504, 516-17. Some have observed the mode as young as between 10 and 20, but this incidence has been attributed to peculiarities of work and living habits that have exposed this group more fully to plague. No one has yet indicated or argued that Yersinia pestis has become a childhood disease anywhere, and no one has charted a significant change in the age structure of victims over time. In the US 60 per cent of cases have been among men and young males because of their outdoor activities and the skinning of diseased carriers such as ground squirrels (see Palmer, op. cit., note 56 above, p. 1570). By contrast, the 1967 plague in Nepal struck principally women and children, because they were the ones to stay in their homes, which F Marc Laforce, et al., 'Clinical and epidemiological observations on an outbreak of plague in Nepal', Bulletin of WHO, 1971, 45: 693-706, speculate were riddled with human fleas. For the plagues in Manchuria, J W H Chun, 'Clinical features', in Wu Lien-Teh, et al., note 10 above, pp. 309-33, p. 320, found "few cases of plague among children and women".

${ }^{60}$ Scott and Duncan, op. cit., note 23 above, p. 45.

${ }^{61}$ For the mortality trends in the fourteenth and fifteenth centuries, see Cohn, op. cit., note 36 above, pp. 192-203, and for the twentieth century, Pollitzer, op. cit., note 41 above, pp. 16-66.

${ }^{62}$ Cited in Hans Zinsser, Rats, lice and history, New York, Little. Brown for the Atlantic Monthly Press, 1935 , p. 89.
} 


\section{Samuel K Cohn Jr}

While Chalmelli's assessment may have been overly sanguine, last wills and testaments ${ }^{63}$ and monastic and confraternal necrologies point in this same downward direction, charting a rapid adaptation between the Black Death pathogen and human hosts. ${ }^{64}$ All of these late medieval records pose problems for quantitative analysis. Although testaments did not pertain only to the "affluent" as some have charged but included peasants, artisans, and even disenfranchized workers (especially in Italian cities), these records concentrate among propertied groups and, perhaps more problematic for demographic trends, do not include infants or many of the young. Nor are burial records without their problems as a demographic record, especially in 1348, when the clerics, who recorded the burials, either died themselves or ran for the hills, as happened in Siena in June of that year. Just as the plague was heating up to a crescendo, these records stop and resume only after the disease had disappeared in late August. For Florence, the Dominican necrologies may be a more precise source for 1348. They give a complete record of deaths and specify whether brothers died of plague or not. These records, however, pertain to a specific group of men, who were cloistered, and as the Black Death was a contagious disease with a high household clustering of cases, the documentation may not provide an equivalent mortality among the general population. Yet these various death records show a remarkable consistency from city to city and amongst themselves within cities where multiple types of records exist for the same period as with Florence.

Along with this steady decline in mortality through the fourteenth century, chronicles across Europe described plagues from 1361 onwards as "plagues of children". The contemporary chronicler of Pisa, Ranieri di Sardo, was more specific than most. By the third plague in 1374 , he recorded that 80 per cent of the plague deaths in his city were among those aged twelve or younger ${ }^{65}$ (precisely the number of years since the last plague had hit Pisa). Statistics drawn from the burial records of Siena confirm Ranieri's report. From the second plague in 1363 to the third in 1374, the proportion of deaths attributed to children rose from a third to over half (136 of 233), and with the fourth in 1383, children had become

\footnotetext{
${ }^{63}$ The samples of testaments used in Cohn, The Black Death transformed (op. cit., note 36 above), varied in their precision and usefulness. Perhaps the most problematic of these were the Court of Husting wills of London. In his review of this book (Bull. Hist. Med., 2004, 78: 212-14), Michael McVaugh charged that the larger collection of wills of the Commissary Court of London shows a very different picture of the decline in mortality in London, with successive plagues of the late fourteenth century attaining numbers of testaments and thus levels of mortalities almost as high as those seen in 1348. McVaugh, however, misleadingly attributes this analysis to Paul Slack and makes no attempt to examine the documents himself. First, these wills do not survive from 1348 but begin only with the third plague in 1374, when, as seen for other cities, the big declines in mortality had already occurred. Furthermore, McVaugh gives no idea of the proportions of plague wills in 1375, 1382, or 1390 in comparison with non-plague years from this source. Mark Fitch's Index to testamentary records to the Commissary Court of London, vol. 1, 1374-1488, London, 1969, indicates that 1390 is the year when the number of wills mounts to their highest point during the late fourteenth century. This point, however, is hardly the sharp spike in mortality that McVaugh claims and that would approach the 1348 levels of mortality. Instead, it shows an increase of only 24 deaths (of 123 total deaths) over the average mortality of 99 calculated from previous non-plague years. By contrast, counts from wills, necrologies, and burial records for 1348 show the death rolls soaring above previous averages by as much as thirty times. By the commissary court wills, plague mortalities relative to average years appear in fact to have fallen even more steeply by 1374 than the trend charted by the Court of Husting wills.

${ }^{64}$ See the charts in Cohn, op. cit., note 36 above, pp. 192-202.

${ }^{65}$ Cronaca di Pisa di Ranieri Sardo, ed. Ottavio Banti, Fonti per la Storia d'Italia, no. 99, Rome, Istituto Storico Italiano, 1963, p. 186.
} 


\section{Epidemiology of the Black Death and Successive Waves of Plague}

a staggering 88 per cent of the plague's victims (230 of 260). ${ }^{66}$ To repeat, the bubonic plague of the twentieth century has never shown this tendency, even in places such as the Punjab, where plague returned annually for twenty or more years and infected larger proportions of the population than anywhere else. ${ }^{67}$

Further differences in the epidemiology and ecology of the late medieval-early modern plague and Yersinia pestis are apparent. As with the first pandemic, chronicle descriptions tallied by Henri Dubois show a close correlation between famine and outbreaks of plague during the late medieval and early modern periods. ${ }^{68}$ By contrast, the opposite has been seen for late nineteenth- and twentieth-century India and elsewhere: ${ }^{69}$ bumper crops have led to higher plague mortalities. From the early twentieth century, plague commissioners in India, Sydney, and other international ports, as well as later in Vietnam in the 1960s and 1970s, discovered that grain deposits were the powder kegs and epicentres of bubonic plague with grain workers usually the first victims. Statistics from the burial records of Florence in 1400 allow a detailed reckoning of the neighbourhood distribution of plague mortality, where the disease first struck, how it spread, and in what wards it proved most lethal. The relationship between grain storage and the dissemination of the late medieval plague can probably be studied better here than elsewhere because of the strict enforcement of grain distribution from a single point in the city, first at Orsanmichele and, after 1367, a hundred or so metres away at the Mercato Nuovo del Grano. Instead of being the first area of affliction or the neighbourhood most severely visited by pestilence, the tiny parishes of

\footnotetext{
${ }^{66}$ Afterwards, in the lesser plagues of 1390 and 1400, the proportion fell to 67 of 151 and 62 of 182 , lower than in 1383 but still higher than in the supposed children's plague of 1363; I necrologi di San Domenico in Camporegio (epoca cateriniana), ed. M-H Laurent, Fontes vitae S. Catherinae senensis historici, 20, Siena, Università di Siena, 1937. The reversal in the proportion of children recorded in plagues after 1383 may have resulted from the record keepers' more precise terminology with terms such as puer parvulus and parvulus et innocens sometimes replacing the vaguer entries of filius or filia without first names. By the late fifteenth and sixteenth centuries with less severe plague and with less frequent strikes, the age of victims drifted upwards. However, as the parish records of seventeenth-century Nonantola and the early modern Milanese necrologies show, the elderly were rarely the victims (see Guido Alfani and Samuel K Cohn Jr, 'Nonantola 1630. Anatomia di una pestilenza e meccanismi del contagio [con riflessioni a partire dalle epidemie milanesi della prima Età Moderna]', Population, forthcoming). Moreover, contemporaries of the sixteenth century were cognizant of the relative immunity of the elderly to plague and tried to explain this in Galenic terms (Ragionamento dello eccellentiss. M. Nicolo Massa sopra le infermita, che vengono dall' aere pestilentiale del presente Anno 1555, Venice, per Giovan Griffio, ad instantia di Giordan Ziletti, 1556, 12r; Giovanni Battista Cavagnino, Compilatione delli veri et fideli rimedii da preservarsi et curarsi dalla peste, con la cura delli antraci, carboni \& giandusse, Brescia, Vincenzo Sabbio, 1576, p. 8; and Discorso di M. Baldassarre Pisanelli bolognese medico di S. Spirito sopra la peste, Rome, heredi d'Antonio Blado, 1577, pp. 25 and 26; Vincenzo Tranquilli, Pestilenze che sono state in Italia da anni MMCCCXI, Perugia, Baldo Salviani, 1576, p. 11. According to plague tracts, health boards solicited the assistance of the elderly because of their immunity to this disease to attend to the plague-stricken in locked houses and the lazaretti (Ragionamento ... Nicolo Massa, 16v; David de Pomis, Brevi Discorsi et efficacissimi ricordi; per liberare ogni città oppressa dal Mal contagioso, Venice, Gratioso Perchacino, 1577, 298r [BAV pagination], and Tranquilli, Pestilenze, p. 20).

${ }^{67}$ See the mortality charts for Yersinia pestis in India, Thailand, Brazil and other places during the twentieth century; Pollitzer, op. cit., note 41 above, pp. 16-27.

${ }^{68}$ Dubois, op. cit., note 47 above, p. 327. Also see Elizabeth Carpentier, 'Famines et épidémies dans l'histoire du XIVe siècle', Annales: E.S.C., 1962, 17: 1062-92, 1076, 1081; and W P Blockmans, 'The social and economic effects of plague in the Low Countries 1349-1500', Revue belge de philologie et d' histoire, 1980, 58: 833-63, p. 863 , who found the same correlation for the fifteenth century.

${ }^{69}$ Among other places, see L Fabian Hirst, The conquest of plague: a study of the evolution of epidemiology, Oxford, Clarendon, 1953, p. 281. For the worsening of economic conditions, drought and famine at Dakar in the early 1940s and "the relatively low endemicity", see Myron Echenberg, Black death, white medicine: bubonic plague and the politics of public health in colonial Senegal, 1914-1945, Portsmouth, NH, Heinemann, 2002, p. 218.
} 


\section{Samuel K Cohn Jr}

and surrounding the grain market were the last to be hit and the least heavily blighted by the plague of 1400. Instead, like typhus or other infectious diseases that haunt primarily the poor, the plague began in the poor parishes on the periphery and then worked its way into the wealthier neighbourhoods of the centre, where in fact Florence's central grain market was located, but never scored here dramatic rises in rates of mortality. ${ }^{70}$

Given, therefore, such wide epidemiological differences on so many fronts, why have historians and scientists been so certain that the Black Death and its successive strikes through the early modern period had the same agent-Yersinia pestis? ${ }^{71}$ Usually scientists point to Boccaccio or occasionally to a handful of chroniclers to insist that contemporary descriptions of swellings were the "unmistakable signs" of the same bubonic plague that was cultured in $1894 .^{72}$ For instance, the immunologist and Nobel Prize winner Sir Macfarlane Burnet judiciously cautioned historians that in order to understand diseases in past times, the scholar must go beyond the signs and symptoms of a disease and study its epidemiological patterns. ${ }^{73}$ When he came to the Black Death and bubonic plague, however, he concluded: "The symptoms are characteristic enough to make it easy to recognize the disease from classical or medieval descriptions." He then went further: "We can be sure that the two greatest European pestilences, the plague of Justinian's reign (A.D. 542) and the Black Death of 1348, were both the result of the spread of the plague bacillus."74

Yet, as health workers in Asia are taught today and as medieval contemporaries were aware, swellings in the lymph nodes are not unique to Yersinia pestis, and cultures of the infected regions must be taken. ${ }^{75}$ Plague doctors such as J W H Chun remarked in the $1930 \mathrm{~s}$

\footnotetext{
${ }^{70}$ On this data, see Cohn, op. cit., note 36 above, pp. 204-6.

${ }^{71}$ In fact, from a meeting at Oslo in October 2005 of scientists working on plague in the twenty-first century, I sense that they now accept that the epidemiology of the Black Death and the bubonic plague of the "third pandemic" are vastly different; 'Plague: bacteriology, evolution, ecology, epidemiology and its impact on human history', 9-12 November 2005, CEES/DNVA, Oslo, Norway. As early as 1913, C J Martin, 'Insect porters of bacterial infections: lecture II: The transmission of plague by fleas', Br. med. J. [11 January 1913], i: 59-68, and, more recently, Professor Lars Walløe have described the epidemiological differences between medieval and early modern plague on the one hand, and the third pandemic on the other. Scientists have nevertheless continued to argue that the two waves of plague were the same disease; see Walløe's Plague and population, op. cit., note 38 above, an English translation of Pest og foletall 1350-1750 (1982).

${ }^{72}$ Only a few such as Lars Walløe have studied thoroughly and systematically the late medieval and early modern clinical evidence from contemporary chroniclers.

${ }^{73}$ Macfarlane Burnet, Natural history of infectious disease, 3rd ed., Cambridge University Press, 1962, pp. 5-6, 296.

${ }^{74}$ Ibid., p. 323. The fourth edition of 1972, updated by David O White, left this remark intact, p. 225. Lloyd Moote and Dorothy C Moote, The Great Plague: the story of London's most deadly year, Baltimore and London, Johns Hopkins University Press, 2004, pp. 279-80, have claimed that "across centuries" the same symptoms have appeared on plague victims.

${ }^{75}$ See Manson's tropical diseases, ed. P H Manson-Bahr, 7th ed., London, 1921, p. 270; Manson's tropical diseases, 19th ed. (op. cit., note 56 above), pp. 359, 594-5; Michael Smith and Nguyen Duy Thanh, 'Plague', in Manson's tropical diseases, ed. G C Cook, 20th ed., London, W B Saunders, 1996, p. 920 . Also, Ell, op. cit., note 49 above, p. 871; and Thomas Butler, Plague and other yersinia infections: current topics in infectious diseases, New York, Plenum Medical, 1983, p. 75. For descriptions of ulcers and apostemes that were not pestilential, see, among other doctors, Guy de Chauliac (Guigonis de Caulhiaco), Inventarium sive chirurgia magna, 2 vols, ed. Michael R McVaugh, Leiden, E J Brill, 1997, vol. 1, pp. 117-22. Also, the doctors at Milan in the late fifteenth and early
} 


\section{Epidemiology of the Black Death and Successive Waves of Plague}

that diseases such as malignant typhus may be indistinguishable in their signs and rapid fatal ending from bubonic plague. He concluded: "Summarizing, we may say that the danger of mistaking plague for other diseases is great."76

Boccaccio and many other chroniclers and physicians from Michele da Piazza in Messina (1347) to doctors of the plagues of 1665 in London, 1720 in Marseilles, and 1743 in Messina did not end their descriptions with the bubo forming in the groin, the armpits, or behind the ears. They added that other "tokens" joined the buboes covering victims' bodies. These so-called "tokens" or lenticulae were carbuncles and pustules of various sizes and colours. In addition, occasionally the buboes themselves are described as migrating and multiplying from the lymph nodes to places not regularly seen in cases of "typical" Yersinia pestis - the penis, vulva, elbow, face, chest, legs and even up the nose (as in the case of an unfortunate Bavarian nobleman in the early fifteenth century, who also had a big one in his groin). ${ }^{77}$ Contemporaries such as the fourteenth-century English chronicler Geoffrey le Baker and the early fifteenth-century Florentine diarist Giovanni Morelli pointed to these pustules as being more deadly than the buboes: the stricken could survive the larger glandular boils but not the lentil-like bumps, "shower of peas giving rise to affliction, messenger of swift death", "brittle coal fragments", to use the words of the Welsh poet Llywelyn Fychan, who lamented the death of his four daughters felled by plague in $1363 .^{78}$ Moreover, through the fifteenth to the eighteenth century, plague doctors and chroniclers continued to point to these smaller pustules and carbuncles accompanying the larger tumours in periods of plague. ${ }^{79}$

By contrast, various editions of Manson's tropical diseases maintain that "carbuncles" are extremely rare in cases of bubonic plague: the only case cited comes from the London plague of $1665 .{ }^{80}$ Over 3,000 clinical reports of plague from hospitals around Bombay City in 1896-97 assembled by Brigadier-General W F Gatacre in $1897,{ }^{81}$ show much the same: less than 5 per cent of plague victims developed more than one plague boil, and in not a single case did these boils migrate from their lymph nodes, nor did smaller spots and pustules spread over victims' bodies. Gatacre concluded that "true carbuncles were never met with any of the Parel patients". ${ }^{2}$ Similarly, in the Glasgow plague of 1900 , the clinical

sixteenth centuries occasionally observed swellings in lymph nodes on corpses that they did not diagnose as plague because other "pestilential accidents" were absent and because the victims were ill with the disease for long periods, and did not succumb in less than a week as did the vast majority of plague sufferers.

${ }^{76}$ For the difficulties in distinguishing plague from other diseases, see Chun, op. cit., note 59 above, pp. $327-31$.

77 'De obitu ducis Johannis et pestis epidemie', in Archiv für Geschichte der Medizin, 1922, 14: 138-40, pp. 138-9.

${ }^{78}$ Chronicon Galfridi le Baker de Swynebroke, ed. Edward Maunde Thompson, Oxford, Clarendon Press, 1889 , p. 100; Morelli, op. cit., note 29 above, p. 207; Galar y beirdd: marwnadau plant/ Poets' grief: medieval Welsh elegies for Children, ed. and tr. Dafydd Johnston, Cardiff, Tafol, 1993, pp. 53-5. For other chroniclers and doctors who saw the pustules as worse than the buboes, see Cohn, op. cit., note 36 above, pp. 60-2.

${ }^{79}$ Such descriptions are omnipresent in the sixteenth-century plague tracts; for an eighteenth-century example, see Mead, op. cit., note 24 above, pp. 5, 153.

${ }^{80}$ Manson's tropical diseases, ed. P H Manson-Bahr, 10th ed., London, 1935, p. 254, and 19th ed., op. cit., note 56 above, p. 593. Also, Robert B Craven, 'Plague', in Infectious diseases: a treatise of infectious processes, ed. P D Hoeprich, M C Jordan, and A R Ronald, 5th ed., Philadelphia, Lippincott, 1994, pp. 1302-11, esp. p. 1307, maintains that viscular and pustular skin lesions occur rarely but cites no cases of them.

${ }^{81}$ Gatacre, op. cit., note 36 above.

${ }^{82}$ Ibid., p. 58. 


\section{Samuel K Cohn Jr}

reports do not describe a single case of pustules or carbuncles forming or any other skin disorder apart from a single bubo or in two cases, two boils (both of which were in the groin). ${ }^{83}$ In addition, with modern bubonic plague 60 to 75 per cent of boils form in the groin, ${ }^{84}$ because fleas generally bite on or below the shins. Although contemporaries occasionally called their plague inguinal, not a single medieval source pointed explicitly to the groin as the bubo's principal site. Instead, from miracle cures found in saints' lives to doctors' reports, the late medieval boils' pride of place was the neck, behind the ears, or on the throat. ${ }^{85}$ By the late fifteenth century, at least in Milan, buboes in the groin and on the hip became the principal node. Yet many more swellings formed outside the three principal lymph nodes than has been thus far described for any twentieth-century plague, "typical" or not: 20 per cent as opposed to less than 2 per cent. ${ }^{86}$

However, plague signs and symptoms, even with bubonic plague in various parts of the world since 1894, have been neither so regular nor so consistent as many textbooks on infectious diseases sometimes describe them or as historians often presume. "Pyogenic, necrotic, infarctive, inflammatory, hemorrhagic, and edematous lesions" forming over modern plague victims are not impossible. ${ }^{87}$ In 1909 Choksy found pustules (which he labelled "cellulocutaneous plague") developing in 3.7 per cent of 13,600 cases of bubonic plague collected at two hospitals in Bombay over the course of twelve epidemics, 1897 to $1908 .^{88}$ From cases in Brazil, Peru, Ecuador, and Chile, Atilio Macchiavello observed in the 1930s and 1940s carbuncles on the wrists and ankles of plague victims forming a day or two before the bubo or simultaneously with it. Further, cutaneous lesions- " petechiae, ecchymoses, pustules, and gangrene, [generally called carbuncles] ... of variable size may appear over the buboes or independent of them, especially on the abdomen or extremities". He also observed "pustular plague eruptions" that at times resembled smallpox, which could occur "on any part of the body" but most often in the gluteal and scapular regions. ${ }^{89}$ Unfortunately, Macchiavello did not quantify the proportion of such cases. But this form of bubonic plague (rarely noticed or at least commented upon by others working in the US, the

\footnotetext{
${ }^{83}$ [A K Chalmers], Glasgow Medical Officer of Health, Report on certain cases of plague occurring in Glasgow, in 1900, Glasgow, Corporation of Glasgow, 1901.

${ }^{84}$ For the upper figure, see Alexandre Yersin's observations from the 1894 plague in Hong Kong, 'La peste bubonique à Hong Kong', Annales de l'Institut Pasteur, 1894, 8: 662-67, p. 663; for the lower figure, see D Palmer, op. cit., note 56 above, p. 1572: "buboes are most commonly found in the groin (60\%) but can be seen in the axilla $(30 \%)$ or cervical area $(10 \%)$ " and "buboes at more than one anatomic site are unusual".

${ }^{85}$ See analysis of these sources in Cohn, op. cit., note 36 above, pp. 78-80, 253-4.

${ }^{86} \mathrm{I}$ am currently working with the death records from Milan (Fondo Popolazione, parte antica) from its earliest ones in 1452 to its last systematic accounts for a major plague in 1523-24. Among other places, see Pollitzer, op. cit., note 41 above, p. 420; and N H Choksy, 'The various types of plague and their clinical manifestations', American Journal of the Medical Sciences, 1909, 138: 351-66, p. 351, found only 1.68 per cent of plague swellings outside the principal three lymph nodes from a sample of 13,600 cases and from 16,132 cases W E Jennings reported none.

${ }^{87}$ Craven, op. cit., note 80 above, p. 1306.

${ }^{88}$ Choksy, op. cit., note 86 above, pp. 351-66. Also, Chun, op. cit., note 59 above, pp. 311, 313, reports that haemorrhages in different parts of the body and "pustules may coalesce and form areas of necrosis, the so-called carbuncles" or "blains" as they were called in the plague of London in 1665, but he did not quantify their frequency. In his tables tallying the positions of buboes and "other situations", plague pustules do not even appear (pp. 314-15). He later classifies cases with vesicles and pustules as "atypical cases" (pp. 321-23).

${ }^{89}$ Atilio Macchiavello, 'Plague', Clinical tropical medicine, ed. R B H Gradwohl, Luiz Benitez Soto, Oscar Felsenfeld, London, H Kimpton, 1951, pp. 444-76, p. 460.
} 


\section{Epidemiology of the Black Death and Successive Waves of Plague}

Soviet Union, India, and China where plague has been endemic in the twentieth century ${ }^{90}$ ), nonetheless differs in two crucial respects from medieval and early modern plague with their own variety of pustules and boils. Chroniclers and doctors from 1348 to the very end of the socalled second pandemic in the eighteenth century saw multiple pustules and carbuncles as an integral part of their plague and as its most deadly sign, more so than the bubo. ${ }^{91}$ By contrast, Macchiavello, Choksy, Chun, and others in the twentieth century concur that these "dark pustules" (sometimes called "plague smallpox") were never very common even in incidents of "atypical plague", and, more critically, they saw their appearance predicting the very opposite outcome from that of Black Death ones: in the twentieth century the pustules have been of low toxicity and their prognosis generally benign. ${ }^{92}$

From at least the beginning of the twentieth century, scientists have noted discrepancies dividing the characteristics of the so-called second and third pandemics. ${ }^{93}$ For the absence of any reports of an epizootic of rats or other rodents in 1348 or thereafter, some such as Philip Ziegler have argued that medieval men and women were too overwhelmed by the terrible loss of human life to notice all those rats that surely covered plague-wreaked streets and houses. ${ }^{94}$ Others such as Jean-Noël Biraben, after a thorough combing of texts,

\footnotetext{
${ }^{90}$ For instance, for the 1904 plague in Hong Kong, Robert Koch reported the following proportions of plague type-63.6 per cent bubonic, 31.4 per cent septicaemic, and 5 per cent pneumonic, but mentioned nothing about a pustular form. Cited by Choksy, op. cit., note 86 above, p. 352. Similarly, in the 3752 cases described in the hospital reports collected by Gatacre, not a single case was described with pustules spreading across the body.

${ }^{91}$ For the comments of Geoffrey le Baker, Giovanni Morelli, a canon from Trent, and other fourteenth and fifteenth-century commentators of plague who saw the pustules as signs that were more deadly than the buboes, see Cohn, op. cit., note 36 above, pp. 59-81. Along with French physicians caring for plague victims at Marseilles in 1719-20, Richard Mead, op. cit., note 24 above, pp. 6-7, divided plague victims into five categories ("classes") and observed, 'Bubo's and Carbuncles, in all of them, except in those of the first class, who were so terribly seized, that they died in a few hours, or at farthest in a Day or two". Also, the clinical descriptions in the Necrologi of Milan during the plagues of 1452,1468,1483,1485, 1503, and 1523 show spots called by a wide variety of names (cum signis violareis, morbellis et accidentibus pestifecis, morbillis rubeis, morbillis violaceis verminumque multitudine, morbillis violareis, morbilis nigris) forming over the bodies of plague victims. Often these victims were also afflicted with larger buboes - the bubone, carbone, dragonzello, etc.-in the lymph glands and most often in the groin or femoral regions. Of 187 plague deaths in 1452, 98 (52 per cent) had accompanying spots or pustules. In the plague of 1523, 478 of 1434 victims were stricken with morbilli that covered their entire bodies. More than half of these (274) also had larger plague swellings. Archivio di Stato, Milano, Fondo popolazione, parte antica, vols. 73 and 87. On the Milanese records, see Ann G Carmichael, 'Contagion theory and contagion practice in fifteenthcentury Milan', Renaiss. Q., 1991, 44 (2): 213-56; idem, 'Epidemics and state medicine in fifteenth-century Milan', in R French, Jon Arrizabalaga, Andrew Cunningham (eds), Medicine from the Black Death to the French Disease, Aldershot, Ashgate, 1998, pp. 221-47; D E Zanetti, 'La morte a Milano nei secoli XVI-XVIII: Apunti per una ricera', Rivista Storica Italiana, 1976, 88 (4): 804-52; and Giuliana Albini, Guerra, fame, peste: crisi di mortalità e sistema sanitario nella Lombardia tardomedioevale, Bologna, Capilli, 1982.

${ }^{92}$ Macchiavello, op. cit., note 89 above, pp. 444-76, esp. 460. Chile in 1903 was stricken with this variety of plague. Also, see Choksy, op. cit., note 86 above, p. 357; and Chun, op. cit., note 59 above, p. 322.

${ }^{93}$ See, for instance, Martin, op. cit., note 71 above, pp. $63-4$.

${ }^{94}$ Philip Ziegler, The Black Death, Harmondsworth, Penguin, 1970, p. 27; and for others who have made similar arguments, see Cohn, op. cit., note 36 above, p. 46. Most recently, Sallares, op. cit., note 1 above, p. 270, has made similar assertions to explain the absence of rats during the first pandemic; see note 10 above. Moote and Moote, op. cit., note 74 above, p. 281, argue: "Dead rats in the alleys and cellars of London in 1665 may not have been present in sufficient number to capture people's attention." But for a plague that killed so many more than any plague of Yersinia pestis plagues since 1894 , especially relative to population, would not more rather than fewer dead rats have been apparent?
} 


\section{Samuel K Cohn $\mathrm{Jr}$}

medieval and early modern, have harvested very few references to rats during plagues and none are descriptions of epizootics. Biraben has instead tried to convince us of the supposed tremendous mortality of rats during plague by pointing to less than a handful of examples such as that at Uelzen in 1576, when one man alone was paid 6 schillings to poison rats in the town. ${ }^{95}$ If so many rats were dying, why did contemporaries throughout Europe and for five centuries not comment on it? In the instance above, what was the explanation for killing still more if so many already littered streets and houses? By contrast, peasants in subtropical regions even going back to the Middle Ages have left traces in records and folklore of rat epizootics when their rat-based disease gave rise to boils and quick death. The appearance of dead and dying rats was the sure sign that they should abandon their dwellings and camp out nearby until the end of the plague season. Why should Europeans alone have been so blind, not only during the horrific events of 1347-51 but with successive and less deadly attacks of this plague to the end of the eighteenth century?

As for differences in seasonality and in particular the spread of plague through winter months in northern Europe, historians have argued that the winter of 1348 was extraordinarily wet and mild, but they have failed to look beyond 1348 and account for the continuation of plagues in places as far north as Lübeck, where last wills and testaments show plague peaking consistently in late October or November through the fourteenth and fifteenth centuries, or to sixteenth- and seventeenth-century reports showing plague peaks in places as far north as Trondheim, Norway, in February. ${ }^{96}$ On the other hand, as already noted, plague in Mediterranean zones (places such as Genoa, Florence, and Naples) continued through the seventeenth century to peak often during the hottest and driest months of the year-the least likely months of plague if a rat-flea was the vector. ${ }^{97}$ Why the north and south of Europe should have had such seasonal differences and variability might prove a valuable key for further understanding the late medievalearly modern plagues. At this point, I have no explanations, but such differences certainly do not accord with the narrow temperature and humidity bands found with the fertility cycles of rat fleas or incidents of Yersinia pestis.

For the mixture of skin disorders-buboes in the lymph glands, migrating buboes, and a host of other pustules that covered plague bodies-microbiologists and medievalists have claimed that the bubonic plague activated a penumbra of disease, possibly typhus and smallpox - and that these diseases account for those other skin disorders not generally seen with twentieth-century plague. They fail to explain, however, why this penumbra of disease suddenly appeared with such ferocity and became even more deadly than the new virgin-soil bubonic disease of medieval plague. Nor do they explain why Yersinia pestis in modern times has never displayed this synergy, suddenly causing an explosion of a wide host of other diseases, much less ones with skin disorders similar to typhus or smallpox but which were more contagious and deadly than these diseases are today.

\footnotetext{
${ }^{95}$ After an exhaustive survey of sources, Biraben, op. cit., note 55 above, vol. 2, p. 333, found only three similar references to rats for thousands of plague incidents across towns and villages in Europe from 1348 to the eighteenth century and none of these refer to dead rats, much less a mass mortality of them.

${ }^{96}$ See the examples in Walløe, op. cit., note 38 above, pp. 25 passim.

${ }^{97}$ See note 42 above.
} 


\section{Epidemiology of the Black Death and Successive Waves of Plague}

Perhaps most vexing for those who wish to label the Black Death Yersinia pestis has been the drastic difference between the transmission of the two diseases: one travelling with astonishing speed and efficiency; the other discovered early on by plague commissioners to have been hardly contagious at all, especially in bubonic form. To resolve this riddle, historians and doctors first turned to pneumonic plague to explain the seeming absence of rats with the Black Death along with its contagion and rapid dissemination. Yet the late medieval plagues especially in the Mediterranean recurred consistently during the hottest months of the year, not the usual time for respiratory diseases and for pneumonic plague in particular to reach their peaks. By the mid-fifteenth century, if not earlier, moreover, descriptions of coughing and spitting blood disappear from records such as the detailed clinical reports of the Milanese necrologies and in doctors' plague tracts; yet the plague continued to be as contagious as earlier, with deaths clustering tightly in families and households. ${ }^{98}$ More damaging still, assumptions that Yersinia pestis in pneumonic form needs no rodents, is highly contagious, and can result in much higher death tolls than in bubonic form are mistaken. The head of the Manchurian plague commissions in 1911 and 1922, Wu Lien-Teh, observed that pneumonic plague, as in its other forms, remains a rodent disease and must begin with an epizootic of rodents. In Manchuria it was the tarabagan, whose furs soared in price in the early twentieth century, leading to an influx of inexperienced trappers into the region. Pneumonic plague can spread person-to-person, especially in the extraordinary conditions in which the tarabagan trappers found themselves, forty or more crammed into unventilated underground huts measuring 15 by 12 feet in sub-freezing temperatures. ${ }^{99} \mathrm{Wu}$, however, observed that the pneumonic form of Yersinia pestis was not, even in these extraordinary circumstances, terribly contagious. He noted that in tightly packed train cars travelling across Manchuria those infected with pneumonic plague rarely passed it on to fellow passengers. As a consequence, the worstknown epidemic of pneumonic plague, that of Manchuria in 1911, infected and killed less than 0.3 per cent of the population affected by the disease. As Wu concluded, it did not spread with anything like the speed or efficiency of influenza or the Black Death (although later in life and further removed from the events of 1911 and 1922, he thought that the Black Death may have been Yersinia pestis). ${ }^{100}$ More recently, Steve Leach of the Centre of Applied Microbiology and Research has shown that pneumonic plague has had low rates of transmission (0.25-.55), much lower than influenza, measles, and many other infectious diseases. ${ }^{101}$ The pneumonic plague that flared in Gujarat, Surat, and other districts and cities of India further substantiate these conclusions: despite this plague's centre in the

\footnotetext{
${ }^{98}$ Cohn and Alfani, op. cit., note 23 above, pp. 204-5.

${ }^{99}$ Wu Lien-Teh, 'First report of the North Manchurian Plague Prevention Service', J. Hygiene, 1913-14, 13: 237-90, expressed doubts about modern and medieval plague as the same but later changed his mind; see also, idem, A treatise on pneumonic plague, Geneva, League of Nations, 1926; idem, 'Historical aspects', in Wu Lien-Teh, et al., op. cit., note 10 above, pp. 1-55; and idem, Plague fighter: the autobiography of a modern Chinese physician, Cambridge, W Heffer, 1959.

${ }^{100}$ Mark Gamsa, 'The epidemic of pneumonic plague in Manchuria, 1910-1911', Past and Present, 2006, 190: $147-84$

101 'Potential transmissibility of pneumonic plague', paper delivered to the University of Warwick, Institute of Mathematics: Mathematics in Medicine Initiative: Bubonic Plague, 27 June 2002; and Raymond Gani and Steve Leach, 'Epidemiologic determinants for modeling pneumonic plague outbreaks', Emerg. Infect. Dis., 2004, 10 (4): 608-14.
} 


\section{Samuel K Cohn Jr}

highly crowded slums of Surat, "almost no confirmed secondary cases were reported in any of the investigations" and in "hardly any family was more than a single member affected". 102

Historians and now many from the scientific community speculate that the human flea, Pulex irritans, was the vector-a proposition first raised cautiously by C J Martin in 1913. If present in great abundance, they argue, this flea might explain the absence of rodents as carriers (at least after an initial outbreak) and the wide differences in epidemiology between the second and third pandemics, that is, the lightning speeds of late medieval plagues, their high contagion, household clustering of cases, and high mortality. According to Martin, however, "A variation of the plague bacillus in the direction of greater infectivity, with perhaps diminished toxicity leading to a higher degree of septicaemia in man" would have needed to exist to explain the direct transmission by human fleas on the scale of the late medieval plagues. ${ }^{103}$

As far as I am aware, the most detailed study of a plague transmitted person-to-person and perhaps by the human flea was that of the 1967 outbreak in the mountain village of Nawra, Nepal. It resulted in six cases of tonsillar plague, ${ }^{104}$ one of primary pneumonic plague and seventeen of the bubonic variety. Unlike bubonic plague in India, Sydney, China, and most other places, plague here clustered tightly in households and could be shown to have been transmitted person-to-person. Further, no epizootic of rodents was reported immediately preceding or accompanying the human plague, "despite persistent inquiry and careful searching". Finally, in the bubonic cases, again unlike classic plague in India and most other places, the buboes did not concentrate in the femoral regions and groin but formed on shoulders, calves, facial and cervical regions. In at least two cases, "multiple Black Spots scattered over the skin prior to death". ${ }^{105}$

So, even if Pulex irritans can explain small-scale epidemics in the twentieth century without evidence of rodent epizootics and with skin disorders that look much more similar to late medieval and early modern plagues than the classic "Indian" variety, should we conclude that the epidemiology of the second pandemic is solved by Pulex irritans? To date, no one has shown that this vector has ever caused an epidemic on any noticeable scale or explained how a flea that is far less efficient in transmitting Yersinia pestis than Xenopsylla cheopis can account for the medieval mortalities that were at least an order

\footnotetext{
${ }^{102}$ Dileep V Mavalankar, 'Indian “plague” epidemic: unanswered questions and key lessons', J. R. Soc. Med., 1995, 58: 547-51, p. 548.

${ }^{103}$ Despite his speculation that Pulex irritans may have transmitted the plague in the Middle Ages, Martin, op. cit., note 71 above, p. 63, admitted: "Nevertheless the direct transmission of the disease from man to man cannot, at the present time, be of frequent occurrence... The reason why the human flea is ineffective is because in human cases the average degree of septicaemia before death is so much less than in rats that the chance of a flea imbibing even a single bacillus is small."

${ }^{104}$ Sallares, op. cit., note 1 above, p. 239, mistakenly asserts that all cases of bubonic plague with swellings in the cervical region consistently produce tonsillar plague and therefore are pneumonic. In fact, tonsillar plague has been extremely rare with outbreaks of "typical bubonic plague". From a study of 13,600 cases of plague in Bombay in 1900, Choksy, op. cit., note 86 above, pp. 351-2, found around 10 per cent of buboes in the cervical region, while only 1.0 per cent were cases of pneumonic plague (either primary with no signs or secondary). Also, see Chun, op. cit., note 59 above, p. 321. Even with the "atypical" plague in Nepal in 1967, when several cases of tonsillar plague were discovered, not all cervical cases were tonsillar or showed pulmonary symptoms; Laforce, et al., op. cit., note 59 above, Table 1, p. 695.

${ }^{105}$ Laforce, et al., op. cit., note 59 above, p. 695.
} 


\section{Epidemiology of the Black Death and Successive Waves of Plague}

of magnitude higher than anything ever scored by Yersinia pestis since its discovery in 1894 and that spread more widely over space in a given period of time by two orders of magnitude and without twentieth-century modes of transportation. ${ }^{106}$ This remarkable difference in transmission is to be explained by a flea that Albert Burroughs and others showed rarely, if became blocked and in the laboratory never transmitted the bacillus to its hosts even in ideal conditions of temperature and humidity. ${ }^{107}$

The plague commissioner Fabian Hirst in the 1950s showed the difficulty in grasping this straw to solve the riddle. First, he argued vigorously that "all the available evidence" points to Pulex irritans as "a feeble transmitter of plague" anywhere in the world and questioned the conclusions of Georges Blanc and Marcel Baltazard that plague in Morocco in the 1930s and 1940s had been transmitted by this flea. He then went further, maintaining that the reverse transmission of plague from humans to rats, other mammals, or other humans was highly unlikely: the concentration of the bacillus in humans is far too low to transmit the plague effectively to other animals or humans. ${ }^{108}$ But when Hirst came to explain the Black Death, for some reason he ignored his earlier conclusions and speculated that its person-to-person spread might be explained by the human flea. Other entomologists, rat specialists, and plague scientists such as Atilio Macchiavello, and even C J Martin, have repeated Hirst's first doubts about this flea transmitting plague in the twentieth century and have connected the severity of plague since 1894 with the prevalence of the most efficient vector, Xenopsyllus cheopis. Along with Graham Twigg, who has put it bluntly, they have concurred: "man is a biological dead end" as far as plague goes. ${ }^{109}$

Even if we reject this axiom and accept the studies of Blanc and Baltazard for Morocco and Iran that implicated the human flea, the "third pandemic" has yet to provide a single such case of an important epidemic scoring over a thousand deaths, and most outbreaks in Iran, northern and central Africa, and Nepal, where Pulex irritans has been suspected as the vector, have counted far fewer casualties. Secondly, while plague transmitted by Pulex irritans might spread rapidly through a single village (as it may have done in Nepal in 1967), it can extend beyond the village only with great difficulty. This failure, moreover, cannot be attributed to efficient medical intervention. In the cases of plague in the mountains of Iran and Nepal, health workers from the Institut Pasteur at Tehran arrived on the scene only after these epidemics had almost completed their course. Even the most

\footnotetext{
${ }^{106}$ After reviewing the arguments for and against human parasites spreading the plague, $\mathrm{C} \mathrm{Y} \mathrm{Wu,} \mathrm{'Insect}$ vectors', in Wu Lien-Teh, et al., op. cit., note 10 above, pp. 249-308, on pp. 296-301, concluded: “. . . in the present state of our knowledge ... human parasites, be they fleas, bed-bugs or lice, are, only under particular circumstances, of practical importance in the spread of human plague and, unlike rat-fleas, are unable to lead to widespread and persistent epidemics of bubonic plague" (p. 301).

${ }^{107}$ Burroughs, op. cit., note 37 above, p. 394, showed that the Indian rat flea, Xenopsylla cheopis, was three times more efficient than any other flea in transmitting plague. In the laboratory the vector efficiency of Xenopsylla cheopsis was found to be $0.660+/-0.234$, while that of the second most efficient, Nosopsyllus fasciatus, was $0.213+/-0.157$. In not a single case was Burroughs able to induce blockage with the so-called human flea, Pulex irritans.

${ }^{108}$ Hirst, op. cit., note 69 above, pp. 238-40, 244, also argued that plague never reached epidemic proportions in Morocco (100 cases per annum) and that there was no evidence to suppose that Xenopsylla cheopis had not been chief vector of plague to humans. Also, see Butler, op. cit., note 75 above, p. 51: "The human flea Pulex irritans is not an efficient plague vector and rarely, if ever, has transmitted plague from man to man."

${ }^{109}$ Graham Twigg, The Black Death: a biological reappraisal, London, Batsford, 1984, p. 170. See also, Pollitzer, op. cit., note 41 above, p. 486, who concurred with Wu Lien-Teh, "human carriers represent ... a sidetrack of the infection which ends blindly".
} 


\section{Samuel K Cohn Jr}

vigorous supporter of human ectoparasites as the vectors of the late medieval, early modern, and twentieth-century plagues, Georges Blanc, recognized these difficulties:

Inter-human contagion is strictly limited to those who enter the mortuaries of plague victims, or who change or wear their clothes. For the most part, they are family members, or of the same farm or hamlet. The transport of infected ectoparasites at any distance is thus nil, the opposite of what happens with typhus. ${ }^{110}$

He then went on, however, to speculate that in urban areas such restrictions on the mobility of the disease would not pertain. And it was there, he suggested, that the late medieval plagues achieved their "réputation catastrophique". But, in addition to failing to explain the rapid and devastating spread of the Black Death or other plagues such as those of 1629-30 through isolated rural districts, such an urban transmission has yet to happen even on a minuscule scale in urban areas since 1894, even in cities such as Dakar and St Louis (Senegal) where both plague and human fleas have been plentiful. Instead, the suspected examples of outbreaks of inter-human plague transmitted by human ectoparasites have come solely from nomadic tribesmen in cold climates or those in desert circumstances such as on the steppes of Russia, ${ }^{111}$ where herdsmen have been accustomed to wearing thick layers of clothing for protection. ${ }^{12}$

These characteristics of plague transmitted by Pulex irritans do not, moreover, tally well with the epidemiology of the Black Death and its subsequent strikes through the early modern period or with the habits and conditions of its people. First, these late medieval and early modern plagues were capable of spreading rapidly from village to village and from one rural region to another even in isolated and sparsely populated mountainous territories such as Snowdonia, ${ }^{113}$ the Apennines of Italy, ${ }^{114}$ and the cantons of Switzerland. ${ }^{115}$ Secondly, the seasonality of the plague especially in the warm Mediterranean does not

\footnotetext{
${ }^{110}$ Georges Blanc, 'Une opinion non conformiste sur la mode de transmission de la peste', Revue d'Hygiène Médicine Sociale, 1956, 4: 535-62, p. 548.

${ }^{111}$ Robert Pollitzer, 'A review of recent literature on plague', Bull. World Health Organ., 1960, 23: 313-400, p. 360 .

${ }^{112}$ Concern and fear for the spread of Yersinia pestis by Pulex irritans appears to have reached a high point with the Bulletin of the World Health Organization's special number on plague in 1960. Pollizter, op. cit., note 111 above, concluded: "Reiterating claims which he had made in the past, Blanc (1956) postulated that human parasites, particularly $P$. irritans, played the main role in the spread of human plague. Evaluating this thesis, one must admit that in areas like Morocco where ... thick layers of clothing and lack of cleanliness tend to increase human infestation with ectoparasites, $P$. irritans is apt to take an important part in the transmission of plague, the high incidence of this species compensating for what it lacks in vector capacity. At the same time, however, it is certain that in other plague areas, for example, China, India and also Madagascar, the role of this flea is negligible, the transmission of the infection depending upon the rat fleas, particularly X. cheopis" (pp. 360-1). The latest plague manual issued by WHO, by contrast, pays far less attention to Pulex irritans, and concern over this flea as a possible plague vector is much more guarded: "Pulex irritans has been considered as a possible or probable vector of plague" (David T Dennis, et al., Plague manual: epidemiology, distribution, surveillance and control, Geneva, World Health Organization, 1999, p. 67).

${ }^{113}$ William Rees, 'The Black Death in England and Wales, as exhibited in manorial documents', Proc. R. Soc. Med., 1922-23, 16: Section of the History of Medicine, p. 30.

${ }^{114}$ See Samuel K Cohn Jr, Creating the Florentine state: peasants and rebellion, 1348-1434, Cambridge University Press, 1999, pp. 226-8.

${ }_{115}$ B Andenmatten and J-D Morerod, 'La peste à Lausanne au XIV siècle (1348/49, 1360): étude du chapitre cathédral et des testaments vaudois', Études de lettres: Revue de la Faculté des lettres de l' Université de Lausanne, 1987, no. 2/3: 19-49; and E A Eckert, 'Seasonality of plague in early modern Europe: the Swiss epidemic of 1628-30', Rev. Infect. Dis., 1980, 2: 952-9.
} 


\section{Epidemiology of the Black Death and Successive Waves of Plague}

correspond with conditions of plagues spread by human ectoparasites, which, if they arise at all, occur when people are wearing extra clothing and using the maximum bedding for warmth or protection against wind and sand. Such clothing habits in summer time are not seen among Florentines or Romans in the Middle Ages or today. As early as the late thirteenth century, Italians had developed spinning technology to weave light summer cloth for their Mediterranean climates. David Herlihy and John Munro have shown that these new fabrics spread to the peasantry and may well have constituted the first massmarket goods in the west. ${ }^{116}$ Elsewhere, after the Black Death, contemporaries hardly give us the impression of people-even the common folk-constantly bundled up to excess in layers of clothing. Indeed, Geoffrey Chaucer, John of Reading, the legislators of new sumptuary laws, and many others complained of luxury clothing penetrating the ranks of commoners, and of the "inordinat scantnesse" of their garments; instead of an excess of clothing, moralists of the late Middle Ages, especially in plague time, complained of new fashions that were "extremely short" and which exposed the arses and "private parts" of men and women alike. ${ }^{117}$

Thirdly, the spread of plague by Pulex irritans makes certain assumptions about medieval life across social classes - that they were all equally dirty, insanitary, and rarely washed themselves, their bedding or clothing. ${ }^{118}$ But late medieval and Renaissance paintings show obsessions with clothing, beauty, and cleanliness now corroborated by economic historians and those studying fashion for wider strata of the population before and especially after the Black Death. ${ }^{119}$ The first several strikes of plague through the fourteenth century did not victimize solely the poor; rather they more or less hit all equally, regardless of social class. In various places chroniclers even commented that the rich fell to

\footnotetext{
${ }^{116}$ David Herlihy, Pisa in the early Renaissance: a study of urban growth, New Haven, Yale University Press, 1958, and John Munro, 'Medieval woollens: the western European woollen industries and their struggles for international markets, c.1000-1500', in David Jenkins (ed.), The Cambridge history of western textiles, 2 vols, Cambridge University Press, 2003, vol. 1, pp. 228-324. For the early modern period, see Paolo Malanima, Il lusso dei contadini: consumi e industrie nelle campagne toscane del sei e settecento, Bologna, Mulino, 1900.

${ }^{117}$ Susan Crane, The performance of self: ritual, clothing, and identity during the hundred years war, Philadelphia, University of Pennsylvania Press, 2002, pp. 11-15; Chronica Johannis de Reading, in Rosemary Horrox (trans. and ed.), The Black Death, Manchester University Press, 1994, p. 133.

${ }^{118}$ See, for example, Ricardo Jorge, 'Summa epidemiologica de la peste: épidémies anciennes et modernes', Bulletin de l' Office International d' Hygiène Publique, 1933, 25 (1): 425-50, p. 448: "When plague invaded Europe almost without respite, everyone, even those from the highest social classes, were overwhelmed and eaten by their ectoparasites; everyone was more or less ridden with fleas [puceaux et pouilleux]." Jorge, however, produces no note or any evidence from the Middle Ages or early modern period to substantiate this assertion. (I thank Lars Walløe for bringing this article to my attention.) By contrast, on the great diversity of clothing allowed by sumptuary legislation from place to place and the strict hierarchy of clothing according to social class, see Maria Giuseppina Muzzarelli, 'Le leggi suntuarie', in Storia d'Italia Annali, 19: La moda, ed. Carlo Marco Belfanti and Fabio Giusberti, Turin, Einaudi, 2003, pp. 185-220.

${ }^{119}$ See references in the previous three notes and Richard Goldthwaite, The building of Renaissance Florence: an economic and social history, Baltimore, Johns Hopkins University Press, 1980, pp. 41-8; idem, Wealth and the demand for art in Italy, 1300-1600, Baltimore, Johns Hopkins University Press, 1993, p.150 passim; Susan Mosher Stuard, Gilding the market: luxury and fashion in fourteenth-century Italy, Philadelphia, University of Pennsylvania Press, 2006; and Evelyn Welch, Shopping in the Renaissance: consumer cultures in Italy, 1400-1600, New Haven, Yale University Press, 2005; for the early modern period, see Patricia Allerston, 'The market in second-hand clothes and furnishings in Venice, c. 1500-c. 1650', PhD thesis, European University Institute, 1996; and Storia d'Italia Annali, 19: La moda, op. cit., note 118 above, esp. Patricia Allerston, 'L'abito usato', pp. 561-81.
} 


\section{Samuel K Cohn Jr}

the disease in greater numbers than the poor. ${ }^{120}$ Certainly by the sixteenth century (and probably well before) doctors recommended changing clothing frequently, ${ }^{121}$ and at least the rich and middling classes could afford to do so; yet plague continued to strike communities with massive epidemic force as in 1575-77, 1629-30, 1656-7, 1709-12, 1719-20, 1743, and 1770-1, and these plagues (after a generation or longer absence from a locale) killed the rich and well attired along with the poor and dirty. ${ }^{122}$

Fourthly, from the plague legislation at Pistoia in $1348^{123}$ to the eighteenth century, communities made strenuous efforts to restrict the movement of goods as well as persons by imposing quarantines; governors and health magistrates were particularly suspicious of clothing, bedding, and textiles as prime culprits in the transmission of plague. More than any other articles, these were subjected to careful scrutiny and, by the eighteenth century, even experimentation in the transmission of plague. ${ }^{124}$ Yet, I know of no account that describes fleas popping out of bedding and clothing like popcorn as has been observed among the articles of herders today, who live in tents with carpets and thick layers of bedding and clothing. ${ }^{125}$ Unlike the microscopic pathogen, whether a bacterium or virus, the human flea, especially in the great numbers necessary for the spread of plague to even a few people in a single village, is visible. ${ }^{126}$ In ancient times as well as the Middle Ages,

\footnotetext{
${ }^{120}$ See, for instance, the observations of the chronicler of the Grey Friars at Lynn during the plague of 1361; Horrox (trans. and ed.), op. cit., note 117 above, p. 86.

${ }^{121}$ Sixteenth-century doctors regularly gave such advice in their plague tracts, see, for instance, Giacomo Filippo Besta, Vera narratione del successo della peste, che afflisse l' inclita città di Milano, l'anno 1576, Milan, Paolo Gottardo and Pacifico Pontij, 1578, 20r; Gratiolo di Salò, op. cit., note 55 above, p. 17; da Marostica, op. cit., note 25 above, 307r-v; Giovan’ Andrea Bellicochi, Avvertimenti di tutto ciò che in publico da Signori \& in privato da ciascuno, si debbe far nel tempo della peste, Verona, Dalle Donne, 1577, 414v.

${ }^{122}$ For the plague in Venice of 1575-77 as one that ripped through all social classes, see Allerston, op. cit., note 119 above, p. 578.

${ }^{123}$ 'Gli ordinamenti sanitari del comune di Pistoia contro la pestilenza del 1348', in Horrox (trans. and ed.), op. cit., note 117 above, pp. 195-203, esp. pp. 195-6. The second of 36 chapters concerns clothing: "No one, whether from Pistoia or elsewhere, shall dare or presume to bring or fetch to Pistoia, whether in person or by an agent, any old linen or woollen cloths, for male or female clothing or for bedspreads; penalty 200 pence, and the cloth to be burnt in the public piazza of Pistoia." For similar legislation in Pisa and Lucca, see Gian Maria Varanini, 'La peste del 1347-50 e i governi dell'Italia centro-settentrionale: un bilancio', in La peste nera: dati di una realtà ed elementi di una interpretazione. Atti del XXX Convegno storico internazionale, Todi, 10-13 ottobre 1993, Spoleto, Centro Italiano di Studi sull'alto Medioevo, 1994, p. 293; for Valencia, see Agustin Rubio, Peste negra, crisis y comportamientos sociales en la España del siglo XIV: la cuidad de Valencia (1348-1401), Universidad de Granada, 1979, pp. 76-81, 119. In later plagues of the sixteenth century, such legislation and concern over clothing becomes more common.

${ }^{124}$ Mead, op. cit., note 24 above, pp. 52, 55-6, 58, 82-92; "I am particularly careful to destroy the Clothes of the Sick, because they harbour the very Quintessence of Contagion" (p. 83). From the late Middle Ages, clothing under suspicion during plague time was burnt, disinfected, or vigorously washed; see Allerston, op. cit., note 119 above, pp. 562, 576-7. Further, soap making was an important trade during the Middle Ages and in cities such as Florence was associated with textile production and the cleaning of cloth.

${ }^{125}$ Conversation with Dr Kenneth L Cage, National Center for Infectious Diseases, Fort Colllins, Colorado, USA. While working in Morocco during the plague years of the early 1930s, Ricardo Jorge commented on his astonishment at the high density of fleas in the tent villages (douars). At around the same time, the entomologist L Raynaud "spoke of places where these fleas had become the masters of streets and dwellings". "In Ecuador, it was also noticed that the abundance of fleas was present in the households stricken by plague", quoted in Jorge, op. cit., note 118 above, p. 448. By contrast, in late medieval and early modern Europe clothing was under constant scrutiny in connection with plague because of bad smells and thus the corruption of the air; yet, despite such scrutiny, no one pointed to insects of any sort; see Allerston, op. cit., note 119 above, p. 561.

${ }^{126}$ Contemporaries did observe insects on the plague dead, but to my knowledge not on those stricken by the disease while they were still alive. In a poem, Eustache Deschamps, Oeuvres complètes, ed. Queux de Saint-Hilaire,
} 


\section{Epidemiology of the Black Death and Successive Waves of Plague}

contemporaries knew about insects and classified them. Albertus Magnus, for instance, described various characteristics of fleas (pulices) - their eggs, biting mechanisms, how they drew blood, their leap, and seasonality. He saw them, however, exclusively as an insect that drew blood from animals, not man. In marked contrast to the flea, he described lice (pediculi) as an insect of man as well as of animals, "generated from the filth that is found in the opening of human skin pores" and "found especially in the seams of clothing". ${ }^{127}$

Finally, with early industrialization to the late nineteenth century or even later, overcrowding, public hygiene and sanitation worsened, infectious diseases rose in intensity, and life expectancies often dipped dramatically below levels of the late Middle Ages and early modern period. ${ }^{128}$ Yet these new levels of filth did not suddenly spark renewed outbreaks of the Black Death in Manchester or Calcutta, despite a probable increase in the density of human ectoparasites. For instance, Pulex irritans became the principal rat flea in Dakar and St Louis (Senegal) by the 1950s. ${ }^{129}$ But despite these being overcrowded urban districts with appalling poverty and sanitary conditions on a par with or worse than nineteenth-century cities in the West, no major epidemics of Yersinia pestis have broken out there in the past fifty years, much less ones that have approximated the horrific mortalities and lightning speeds of the Black Death or any which have depended principally on the human flea as its vector. ${ }^{130}$ Instead, with the spread of Pulex irritans as a major flea in Dakar and St Louis, outbreaks and cases of Yersinia pestis declined. The two trends, moreover, may be related.

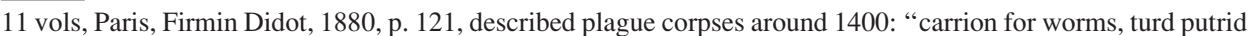
and vile, ... garnished with lice, louse-eggs, and filth, piss, spittle" (trans. in Rudolph Binion, Past impersonal: group process in human history, DeKalb, IL, North Illinois University Press, 2005, p. 131).

${ }^{127}$ See Malcolm Davies and Jeyaraney Kathirithamby, Greek insects, New York, Oxford University Press,1986; and Albert the Great, Man and the Beasts, trans. James J Scanlan, Binghampton, Medieval and Renaissance Texts and Studies, 1987, pp. 437-9. In addition, doctors from the fifteenth to the eighteenth century frequently observed the appearance of worms (vermi) accompanying many cases of plague. Such worms may have been as small or smaller than fleas or lice. Early modern plague writers such as the Abruzzese doctor Sebastiano Tranzi, Trattato di peste, Rome, per gl'heredi di Giovanni Gigliotto, 1587, pp. 9-10, held that the increase in numbers of "flies, frogs, grey mice [sorici], bed bugs, fleas, crickets, butterflies and other such animals born of putrefaction" were a sign of impending plague. Such comments show an awarness of the insect world and a call to observe it in time of plague. Yet, no writer observed insects on plague patients.

${ }^{128}$ According to E H Phelps-Brown and Sheila Hopkins, 'Seven centuries of the prices of consumables compared with builders' wage rates', in E M Carus-Wilson (ed.), Essays in economic history, 3 vols, London, Edward Arnold, 1954-1962, vol. 2, pp. 179-96, the real wages of builders did not return to their high point of the mid-fifteenth century until the $1880 \mathrm{~s}$. On the decline in standard of living, longevity, and sanitary conditions in Britain, see Eric J Hobsbawm, 'The British standard of living 1790-1850', Econ. Hist. Rev., 1957, 10: 46-68; idem, 'The standard of living during the industrial revolution: a discussion', in Econ. Hist. Rev., 1963, 16: 119-34; Greenwood, Epidemics and crowd-diseases, op. cit., note 51 above; and George Rosen, A history of public health, New York, MD Publications, 1958, pp. 201-93. On life expectancies from Elizabethan times, see E A Wrigley and R S Schofield, The population history of England 1541-1871: a reconstruction, Cambridge University Press, 1989. On nutritional and environmental deterioration in nineteenth-century Britain, see Deborah Oxley, "'The seat of death and terror": urbanization, stunting, and smallpox', Econ. Hist. Rev., 2003, 56 (4): 623-56.

${ }^{129}$ Pollitzer, op. cit., note 111 above, p. 357.

${ }^{130}$ Dakar experienced a major plague in 1914 , but there is no evidence that Pulex irritans played any role, despite its possible prevalence as a rat-flea; see Pollitzer, op. cit., note 41 above, pp. 37-8. According to Echenberg, op. cit., note 69 above, pp. 211-43, Dakar's last significant plague occurred in 1944, that is, just before Pulex irritans became the region's most significant rat-flea. Perhaps the increase in Pulex irritans was beneficial in dampening the possibilities of the spread of plague to humans, instead of the opposite as scientists now speculate. 


\section{Samuel K Cohn Jr}

More recently, researchers have claimed to have discovered ancient DNA in tooth marrow from early medieval, late medieval, and early modern grave pits thus "putting to an end" the controversy over what the Black Death was. Geneticists and archaeologists such as Mike Prentice, Alan Cooper, Thomas Gilbert, Carsten Pusch, and others have cast doubts on these claims on several fronts-laboratory contamination, misused methods, and the absence of such results in well-preserved plague pits in Britain, Denmark, France, and Italy. ${ }^{131}$ Let us suppose, however, that medical opinion will accept the claims of Michel Drancourt, Didier Raoult, and their team: that Yersinia pestis was the causal agent of these earlier European pandemics. ${ }^{132}$ Would the riddle of the Black Death then be suddenly solved? Or would such a result instead open new problems and questions for microbiologists, geneticists, others in the scientific community, and historians? How in the space of a century (but perhaps even less given the evidence from nineteenth-century Russia ${ }^{133}$ ) would a disease that once spread quickly and efficiently, person-to-person without the complexities of a rodent carrier or an insect vector, have suddenly become transformed into the inefficient, barely contagious bubonic plague, whose agent was first cultured in 1894 ? Why would this pathogen have suddenly withdrawn from its previous pathways toward symbiosis with its human host? Why would humans, who once possessed natural immunity to this pathogen and could acquire it over the long term, suddenly have lost these characteristics? What biological event in the nineteenth century led to such a quick and radical genetic mutation in both humans and bacteria at precisely the same moment and not just in one or two locales but across the globe? These are questions the historian cannot answer, but which multidisciplinary research and cooperation (as seen at the Oslo conference in November 2005) might help to unravel. Both camps-those who believe the Black Death was Yersinia pestis and those who doubt it-must now be open to new possibilities. As Robert Pollitzer commented in 1960: "Plague is a disease of so protean a character that it would be misleading to generalize the results of observations in one or a few areas, however suggestive they appear to be." 134 For the moment can we agree: the signs and symptoms of both pandemics - the bubonic plagues of late medieval and early modern Europe on the one hand, and those touched off in the late nineteenth century on the other-were hardly so "unmistakable" as to end all debate on the agency and character of these two diseases? Even if new advances in palaeopathology should one day settle the question that Yersinia pestis was the agent of all three pandemics, historians and scientists would then be confronted with new questions: how and why did the epidemiology of the "third" differ so radically from the first two?

\footnotetext{
${ }^{131}$ M B Prentice, T Gilbert, and A Cooper, 'Was the Black Death caused by Yersinia pestis?', Lancet Infectious Diseases, 2004, 4 (2): 72; M Thomas P Gilbert, et al., 'Response to Drancourt and Raoult', Microbiology, 2004, 150: 264-5; M Thomas P Gilbert, et al., 'Absence of Yersinia pestis-specific DNA in human teeth from five European excavations of putative plague victims', Microbiology, 2004, 150: 341-54; Carsten M Pusch, et al., 'Yersinial F1 antigen and the cause of Black Death', Lancet Infectious Diseases, 2004, 4 (8): 484-5.

${ }^{132} \mathrm{Few}$ have, in fact, corroborated the findings of the Marseilles team; for the latest of these scientists' results, see G Aboudharam, M Drancourt, O Dutour, H Martin, D Raoult, and M Signoli, 'Validation de la saisonnalité des décès et authenticité biologique de la nature de l'épidémie', in Bizot, et al. (eds), op. cit., note 56 above, pp. 63-7.

${ }^{133}$ See note 5 above.

${ }^{134}$ Pollitzer, op. cit., note 111 above, p. 361.
} 